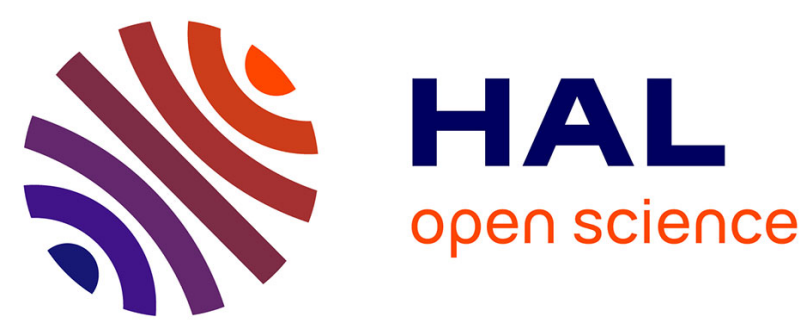

\title{
Development of a new flowsheet for co-separating the transuranic actinides: The "EURO-GANEX" process
}

Michael Carrott, Katie Bell, Jamie Brown, Andreas Geist, Colin Gregson, Xavier Hères, Chris Maher, Rikard Malmbeck, Chris Mason, Giuseppe

Modolo, et al.

\section{To cite this version:}

Michael Carrott, Katie Bell, Jamie Brown, Andreas Geist, Colin Gregson, et al.. Development of a new flowsheet for co-separating the transuranic actinides: The "EURO-GANEX" process. Solvent Extraction and Ion Exchange, 2014, 32 (5), pp.447-467. 10.1080/07366299.2014.896580 . cea-03541573

\section{HAL Id: cea-03541573 https://hal-cea.archives-ouvertes.fr/cea-03541573}

Submitted on 24 Jan 2022

HAL is a multi-disciplinary open access archive for the deposit and dissemination of scientific research documents, whether they are published or not. The documents may come from teaching and research institutions in France or abroad, or from public or private research centers.
L'archive ouverte pluridisciplinaire HAL, est destinée au dépôt et à la diffusion de documents scientifiques de niveau recherche, publiés ou non, émanant des établissements d'enseignement et de recherche français ou étrangers, des laboratoires publics ou privés. 
Demonstration of a new flowsheet for co-separating the transuranic actinides: the "EURO-GANEX" process

Michael Carrott, ${ }^{1}$ Katie Bell, ${ }^{1}$ Jamie Brown, ${ }^{1}$ Andreas Geist, ${ }^{2}$ Colin Gregson, ${ }^{1}$ Xavier Hères ${ }^{3}$, Chris Maher, ${ }^{1}$ Rikard Malmbeck, ${ }^{4}$ Chris Mason, ${ }^{1}$ Giuseppe Modolo, ${ }^{5}$ Udo Müllich, ${ }^{2}$ Mark Sarsfield, ${ }^{1}$ Andreas Wilden, ${ }^{5}$ Robin Taylor ${ }^{1 *}$

${ }^{1}$ National Nuclear Laboratory, Central Laboratory, Seascale, CA20 1PG, United Kingdom

${ }^{2}$ Karlsruher Institut für Technologie, Institut für Nukleare Entsorgung, Karlsruhe, Germany ${ }^{3}$ CEA, Nuclear Energy Division, Marcoule, France

${ }^{4}$ European Commission, Joint Research Centre, Institute for Transuranium Elements (ITU), Karlsruhe, Germany

${ }^{5}$ Forschungszentrum Jülich GmbH, Institut für Energie- und Klimaforschung (IEK-6), Nukleare Entsorgung und Reaktorsicherheit, 52425 Jülich, Germany

* Corresponding Author: robin.j.taylor@nnl.co.uk 
A flowsheet for a novel GANEX ( Grouped ActiNide EXtraction) process has been tested in a spiked flowsheet trial in a 32 stage plutonium-active centrifugal contactor rig with a simulant feed that contained $10 \mathrm{~g} / \mathrm{L}$ plutonium as well as some fission products and other transuranic actinides. The solvent system used was a combination of $0.2 \mathrm{~mol} / \mathrm{L} \mathrm{N}, \mathrm{N}, \mathrm{N}$ ',N'-tetraoctyl diglycolamide (TODGA) and $0.5 \mathrm{~mol} / \mathrm{L} \quad \mathrm{N}, \mathrm{N}^{\circ}$-(dimethyl-N,N'-dioctylhexylethoxymalonamide (DMDOHEMA) in a kerosene diluent that co-extracted actinides and lanthanides. Actinides were subsequently selectively co-stripped away from the lanthanides using a sulphonated and, therefore, hydrophilic bis-triazinyl pyridine (BTP) complexant in conjunction with acetohydroxamic acid (AHA). Plutonium and americium recoveries were high with decontamination factors across the strip contactors of $\sim 14,000$ and $\sim 390$ respectively. However, approximately $30 \%$ of neptunium was lost to the aqueous raffinate which was due to recycling within the first extract-scrub section causing a large build-up of neptunium. Some accumulation of strontium was also observed but in this case it was fully directed to the raffinate stream. In the stripping section, a small fraction of europium (taken as a model lanthanide ion), $c a .7 \%$, was found in the actinide product stream. Modelling of selected data using the PAREX code has shown that, even with a relatively simplistic treatment, reasonable agreement between modelling and experiment can be obtained; giving confidence in the use of modelling to refine the GANEX flowsheet design prior to further testing with irradiated fast reactor fuel.

Key words: plutonium, TODGA, DMDOHEMA, BTP, reprocessing, minor actinides, GANEX 


\section{INTRODUCTION}

\section{Background}

In the development of more sustainable nuclear fuel cycle options, a future potential scenario involves the transition from thermal reactors to fast reactors with a closed fuel cycle to recycle actinide elements. This enables the more efficient utilisation of resources as well as waste management of the long lived or heat generating minor actinides (so-called 'partitioning and transmutation')[1-2]. In Europe, two recycling scenarios are proposed: (i) the heterogeneous recycling of the actinides using a modified version of the well known PUREX process followed by additional processes (such as DIAMEX, SANEX or EXAm processes) for the separate recycling of the major and minor actinides; (ii) the homogeneous recycling of all

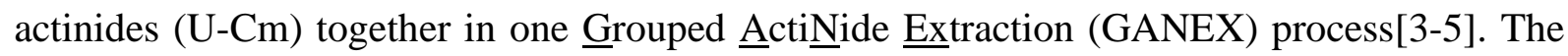
GANEX process is expected to involve two solvent extraction cycles, firstly removing the bulk uranium and then recovering the transuranic elements in the $2^{\text {nd }}$ cycle and is primarily directed towards recycling fast reactor fuels[6-9]. The selective uranium extraction is relatively straight forward using the monoamide solvent N,N-di(2-ethylhexyl)isobutyramide (DEHiBA), which has been demonstrated with spent nuclear fuel[8], or the UREX process which uses tri-butyl phosphate[10]. The $2^{\text {nd }}$ GANEX cycle is more problematic. One proposal using a combination of DMDOHEMA (N,N`-(dimethyl-N,N`-dioctylhexylethoxymalonamide) and HDEHP (di(2-ethylhexyl)phosphoric acid) extractants has been tested using spent fuel solution with promising results[9]. Alternatively, we have been investigating the potential applications of TODGA (N,N,N',N'-tetraoctyl diglycolamide) in the GANEX process, as this has been shown to be a very good extractant for trivalent and tetravalent actinide ions, as well as the trivalent lanthanide ions, although it has rather low loading 
capacities for metal ions[11-17] and forms precipitates with concentrations of $\mathrm{Pu}(\mathrm{IV})$ ions above a few grams per litre[18]. Loading can be improved by the addition of phase modifiers and in particular when combined with the malonamide ligand DMDOHEMA in a kerosene diluent the plutonium loading capacity is significantly increased and precipitation avoided[1819]. Recent publications have described the development of this solvent system[18]; the coextraction of lanthanides and actinides[19]; the use of a novel 'hold-back' reagent, trans-1,2diaminocyclohexane-N,N,N',N'-tetraacetic acid (CDTA), to suppress the undesirable coextraction of zirconium and palladium[20] and the rather complex behaviour of neptunium in this system[21].

We now report the results of a 'spiked' flowsheet test of this conceptual GANEX process in which the actinides were recovered from a simulant feed solution containing actinides and fission products in nitric acid. As this process was developed as part of the "ACSEPT" project funded by the European Union's $7^{\text {th }}$ Framework Programme[3], we have labelled this flowsheet "EURO-GANEX" to differentiate it from variations developed elsewhere, most notably the CEA-GANEX process[9], which is in some respects similar to the present work, as well as the GANEX process under development at Chalmers University, Sweden[22].

\section{GANEX flowsheet concepts}

Fig. 1 schematically illustrates the process flowsheet. The transuranic actinides and lanthanides from the first GANEX cycle raffinate are co-extracted into the solvent phase. The loaded solvent phase then needs to be scrubbed to remove specific problematic fission products and to reduce the acid carried over into the stripping sections. In the stripping sections, firstly, the actinides are stripped away from the lanthanides using complexing agents 
that are selective for trivalent and tetravalent actinide ions over lanthanide ions. For this purpose we developed an aqueous soluble version of the bis-triazinyl pyridine (BTP) ligands[23]. BTP, when dissolved in an organic diluent, are well known for their selectivity for An(III) over Ln(III)[24-25]. The aqueous phase BTP ligand is also capable of stripping plutonium(IV) ions[26]. As neptunium may be at least partly in the hexavalent oxidation state, reduction to $\mathrm{Np}(\mathrm{V})$ or $\mathrm{Np}(\mathrm{IV})$ is required using an organic reducing agent that has fast kinetics. Whilst a number of possible reductants exist, we chose acetohydroxamic acid (AHA) [27] which has the added advantage being a good complexing agent for actinide(IV) ions in $\mathrm{HNO}_{3}[28-29]$. Finally, the lanthanides and other residual fission products are stripped, using a combination of high $\mathrm{pH}$ and/or complexing agent such as glycolic acid[30]. It is anticipated that the solvent raffinate can then be washed and recycled although further experimental studies are required to confirm this assumption. Essentially, therefore, this flowsheet is similar to the CEA-GANEX process in that actinides and lanthanides are co-extracted and then separated from each other by a selective stripping of the actinides. The key differences are (a) that the stripping is performed at 'process' acidities (i.e. $>0.1 \mathrm{~mol} / \mathrm{L} \mathrm{HNO}_{3}$ ) rather than solutions buffered to $\sim \mathrm{pH} 2-3$ and (b) the avoidance of plutonium reduction to $\mathrm{Pu}(\mathrm{III})$. These factors will make the process easier to engineer, control and operate. The flowsheet can thus be compared to the innovative or i-SANEX process[31-33] but with the added complication of needing to control plutonium and neptunium ions which will be present in higher oxidation states (IV, V, VI) and significantly higher concentrations (up to $40 \mathrm{~g} / \mathrm{L} \mathrm{Pu}$ ). 


\section{Experimental Methods}

\section{Reagents}

The standard organic phase ("GANEX" solvent) was a solvent consisting of $0.2 \mathrm{~mol} / \mathrm{L}$ TODGA (ICIQ, Spain and Technocomm Ltd., UK) with $0.5 \mathrm{~mol} / \mathrm{L}$ DMDOHEMA (Pharmasynthèse, France) in an Exxsol D80 (odourless kerosene) diluent. A number of aqueous feeds were also prepared, including a simulant active feed and stripping solutions. The active feed was prepared using range of radionuclides and non-radioactive metals in $\mathrm{HNO}_{3}$. The composition of the active feed solution is given in Table 1 and was designed to simulate the essential components of a High Active feed solution for the GANEX process (after uranium extraction). CDTA was added to the active feed solution in order to suppress the co-extraction of zirconium and palladium. The selective stripping of plutonium and minor actinides from the solvent was achieved using an aqueous strip containing sulphonated 2,6bis(1,2,4-triazin-3-yl)-pyridine $\left(\mathrm{SO}_{3}\right.$-Ph-BTP - in-house synthesis at KIT-INE[23]) and acetohydroxamic acid (AHA) (Merck). Plutonium was acquired from Sellafield Ltd. (as plutonium (IV) nitrate) from Magnox reprocessing operations; this contained amercium-241

from radioactive decay of ${ }^{241} \mathrm{Pu}$. NNL stocks of neptunium $\left({ }^{237} \mathrm{~Np}\right)$ were used for prearation of the active feed. A stock solution of neptunium in $5 \mathrm{~mol} / \mathrm{L}$ nitric acid was prepared and left for two weeks to allow the $\mathrm{Np}(\mathrm{V}) / \mathrm{Np}(\mathrm{VI})$ ratio to equilibrate before mixing with the active feed [34]. An aqueous solution of $0.1 \mathrm{~mol} / \mathrm{L}$ glycolate was prepared using a mixture of glycolic acid and sodium glycolate to provide an aqueous strip at $\mathrm{pH} 4$ to backwash residual lanthanides from the solvent raffinate.

\section{Extract-Scrub Section}


The flowsheet tested is illustrated in Fig. 2 together with the feed compositions and flowrates. The solvent feed (0.5 mol/L DMDOHEMA and $0.2 \mathrm{~mol} / \mathrm{L}$ TODGA in Exxsol D80) was introduced at stage 1 into the extract-scrub contactors. A scrub acid feed of $0.5 \mathrm{~mol} / \mathrm{L} \mathrm{HNO}_{3}$ was introduced at stage 16 of the extract-scrub contactors to provide efficient scrubbing of strontium and iron from the solvent. Both strontium and iron are extracted by the solvent and low acidity in the scrub was required to prevent breakthrough into the strip contactors.

The active feed for the trial was introduced between stages 8 and 9 in the extract-scrub section. A plutonium concentration of $10 \mathrm{~g} / \mathrm{L}$ was selected for this trial, as this would represent a feed similar to mixed oxide (thermal MOx) type fuels and was well within the $3^{\text {rd }}$ phase boundary[19]. This represented a significant step up from testing of the CEA-GANEX process, which used LWR (light water reactor) uranium oxide fuel ( $2 \mathrm{~g} / \mathrm{L} \mathrm{Pu})[8-9]$, and also was consistent with the planned hot test of this EURO-GANEX process on a diluted fast reactor spent fuel solution. The minor actinide species in the active simulant were represented by americium and neptunium. Neptunium was added at $200 \mathrm{mg} / \mathrm{L}$ to allow the routing to be readily followed in the product and profile samples. Concentrations of ${ }^{241} \mathrm{Am}$ were minimised for radiological reasons by simply utilising the americium present in the plutonium stock solution as a daughter product from the decay of ${ }^{241} \mathrm{Pu}$ (sufficient for this spiked test). Fission product species were added at similar concentration levels to those used in high active raffinate simulants elsewhere[20, 30, 35]; these included $700 \mathrm{mg} / \mathrm{L}$ zirconium and $171 \mathrm{mg} / \mathrm{L}$ palladium. Lanthanides in the simulant were represented by cerium, neodymium, europium, dysprosium and holmium. The total fission product concentration for the mass range of 83 to 165 was approximately $3.9 \mathrm{~g} / \mathrm{L}$, consistent with the composition of active feed to be used for the hot test. The iron concentration in the feed was approximately $0.2 \mathrm{~g} / \mathrm{L}$. Tracers were used 
to follow the routing of selected fission product species in the profile and product samples, including ${ }^{152} \mathrm{Eu},{ }^{137} \mathrm{Cs}$ and ${ }^{85} \mathrm{Sr}$. The feed acidity was $5 \mathrm{~mol} / \mathrm{L}$ nitric acid and $0.05 \mathrm{~mol} / \mathrm{L}$ CDTA (trans-1,2-diaminocyclohexane-N,N,N',N'-tetraacetic acid) was added to the active feed in order to suppress the extraction of zirconium and palladium[20]. CDTA was added to the active feed on the day of the trial, approximately 3 hours before the active feed was introduced to the contactors, to allow time for it to effectively complex zirconium and palladium.

\section{Strip Section}

The loaded solvent phase from the extract-scrub section was introduced between stages 20 and 21 of the TRU (transuranic) actinide strip section. Aqueous strip solutions were made up of AHA and $\mathrm{SO}_{3}-\mathrm{Ph}-\mathrm{BTP}$ in $0.5 \mathrm{~mol} / \mathrm{L} \mathrm{HNO}_{3}$ and introduced at stages 24 and 28 to selectively strip the actinides from the loaded solvent. This double strip configuration provided two regions with differing $\mathrm{SO}_{3}$-Ph-BTP concentrations; $0.054 \mathrm{~mol} / \mathrm{L} \mathrm{SO}_{3}$ - $\mathrm{Ph}-\mathrm{BTP}$ in stages 21 to 24 to strip americium from solvent in the presence of high plutonium concentrations and $0.018 \mathrm{~mol} / \mathrm{L} \mathrm{SO}_{3}-\mathrm{Ph}-\mathrm{BTP}$ in stages 25 to 28 to give the solvent a final polish, stripping residual americium and plutonium whilst minimising stripping of the lanthanides. A fresh solvent feed was introduced at stage 17 of the actinide strip section in order to re-extract any lanthanides that were co-stripped with the actinide product. After actinide stripping the solvent entered the final bank of contactors at stage 29 where it was contacted with $0.1 \mathrm{~mol} / \mathrm{L}$ glycolic acid / sodium glycolate mixture at $\mathrm{pH} 4$ to strip residual lanthanides.

\section{Operations}


Initially, the contactors $(1 \mathrm{~cm}$ rotor diameter, INET, China) were flooded with non-active aqueous and solvent phases to establish the required solvent to aqueous ratios and acid profiles in the contactors. This also ensured that operation of the contactors was stable before introduction of the active feed. During this stage the active feed was substituted with $5 \mathrm{~mol} / \mathrm{L}$ nitric acid to ensure that the correct acid concentration profile was obtained in the extractscrub section of the flowsheet. Once the aqueous and solvent phases were exiting from the respective product outlets without any visible entrainment the non-active feed was changed over to the active feed.

At approximately one hour intervals the rotor speeds and product flow rates were measured and samples from the AP1, AP2, AP3 and SR1 streams were taken. The flowsheet run-up to steady state operation was observed by monitoring the plutonium concentration in the AP2 product by on-line electronic absorption spectrophotometry (EAS) (see Fig. 3). After completion of the trial all contactors and pumps were stopped and profile samples taken from each of the contactor stages.

A rotor speed of $4500 \mathrm{rpm}$ was used for the extract-scrub contactors. The flowsheet was stable under these conditions and no entrainment was observed in the aqueous raffinate. During previous trials (not reported) the strip contactors were operated at $4500 \mathrm{rpm}$ and entrainment of solvent was observed in the aqueous actinide product. Subsequent tests showed that this entrainment was dependent upon the rotor speed and could be prevented by operating at lower rotor speeds. Therefore, the rotor speeds for the strip contactors were reduced to $4000 \mathrm{rpm}$ in this test and consequently no hydrodynamic problems were encountered. 


\section{Analysis}

On-line analysis of the AP2 product was performed using a Zeiss MCS501 diode array UVVis spectrometer. The spectrometer was connected to a variable path length flow cell using $600 \mu \mathrm{m}$ i.d fibre optic cables. Spectra were recorded over a wavelength range of 500 to 1000 $\mathrm{nm}$ at intervals of 2 minutes. The absorbance of the $\mathrm{SO}_{3}-\mathrm{Ph}-\mathrm{BTP}$ complex with $\mathrm{Pu}(\mathrm{IV})$ at 792 $\mathrm{nm}$ was monitored to observe the run-up of the flowsheet and confirm steady state operation.

Product and profile samples were analysed by gamma spectroscopy on a DSG HPGe photon detector, Model GC10, connected to an Ortec DSPEC jr. digital gamma ray spectrometer operated using Ortec GammaVision-32 software Version 6. The detectors are calibrated for energy, resolution (Full Width Half Maximum) and efficiency using a mixed gamma nuclide reference standard (QCY48 supplied by HTSL and traceable to national standards). The concentrations of plutonium, americium, neptunium, europium, caesium and strontium in the profile and product samples were determined using the following radionuclides; ${ }^{241} \mathrm{Pu}$ $(148.6 \mathrm{keV}) ;{ }^{241} \mathrm{Am}(59.6 \mathrm{keV}) ;{ }^{152} \mathrm{Eu}(344.3 \mathrm{keV}) ;{ }^{237} \mathrm{~Np}(86.5 \mathrm{keV}) ;{ }^{137} \mathrm{Cs}(661.7 \mathrm{keV})$ and ${ }^{85} \mathrm{Sr}(514 \mathrm{keV})$. The analysis of americium and neptunium by gamma spectroscopy was complicated by coincident gamma peaks from ${ }^{237} \mathrm{U}(59.5 \mathrm{keV})$ and ${ }^{233} \mathrm{~Pa}(86.5 \mathrm{keV})$ respectively. Therefore, corrections were applied to account for the contributions from these nuclides using the gamma peaks for ${ }^{237} \mathrm{U}(208 \mathrm{keV})$ and ${ }^{233} \mathrm{~Pa}(311.9 \mathrm{keV})$.

The final samples from AP1, AP3 and SR1 streams taken under steady state conditions were also analysed by total-alpha and alpha spectroscopy to provide a more accurate assessment of the loss of plutonium and neptunium to these streams. The solvent product from the extract 
Flowsheet test of the GANEX process

section and solvent profile sample from stage 28 were also analysed by total-alpha and alpha spectroscopy to allow the decontamination factor to be determined for plutonium across the actinide backwash contactors. 


\section{Results and discussion}

\section{Overall Performance}

\section{Mass balance}

The results from analyses of the product samples and the calculated mass balances across the flowsheet are summarised in Tables 2-3 for actinides and some key fission products respectively. The low mass balances obtained for the earlier samples indicate that the flowsheet had not reached steady state for the majority of species until almost 4 hours operation with the active feed. In general, good mass balances, between 95 and $105 \%$, were observed for plutonium, americium, europium, caesium and strontium once the flowsheet had reached steady state, although the mass balance for neptunium remained less than $80 \%$. The on-line data for plutonium concentration in AP2, measured by EAS, showed good good agreement with the off-line gamma spectroscopy results (Fig. 3). The poor mass balance for neptunium is suspected to be due to recycle of neptunium in the contactors that prevented neptunium reaching steady state concentration in AP2 (see Stage Profiles below) although it may have been due, in part at least, to difficulties in analysis of neptunium in AP2 where there was a high plutonium concentration.

\section{$\underline{\text { Extract-Scrub Section }}$}

Analysis of the final aqueous raffinate samples confirmed that recoveries of $>99.999 \%$ plutonium and $99.99 \%$ americium were obtained in the extract-scrub contactors. Europium $(>99.6 \%)$ was also routed, as expected, with the solvent product. However, both alpha and 
gamma spectroscopy results agreed that only partial extraction of neptunium, approximately $70-75 \%$, was achieved in the extract-scrub contactors. The ${ }^{237} \mathrm{~Np}$ alpha spectroscopy results, considered to be more accurate than the gamma spectroscopy, indicated $29 \%$ of the neptunium was present in the aqueous raffinate. Both caesium and strontium were routed completely to the aqueous raffinate. However, the results for strontium showed that it took much longer to attain steady state, suggesting that there was significant recycle of strontium within the extract-scrub contactors.

\section{$\underline{\text { Actinide strip }}$}

At steady state a final plutonium concentration of approximately $5 \mathrm{~g} / \mathrm{L}$ was obtained in AP2. The DF for plutonium across the actinide strip (stages 18-28) was calculated based on alpha spectroscopy results for the loaded solvent feed to stage 21 and solvent product from stage 28 . These results indicated that the strip contactors provided a DF for plutonium of $\sim 14,000$. Similarly, the DF for americium across the actinide strip was $~ 390$, based on gamma spectroscopy. Analysis of the actinide product also showed that at steady state there was some loss, $\sim 7 \%$, of europium to AP2. Previous batch distribution studies had shown that the heavier lanthanides have lower distribution ratios than europium (unpublished data). Therefore, it is reasonable to expect that a higher proportion of the heavier lanthanides were present in the plutonium product.

\section{Lanthanide strip}

The results for the lanthanide product (AP3) confirmed that the glycolic acid strip effectively backwashed europium from the solvent (SR1, Table 3). The product samples taken when the 
flowsheet was operating under steady state conditions showed that $>87 \%$ of europium was routed to AP3. Plutonium in the AP3 product was determined in the final three samples by alpha spectroscopy and results showed less than $0.003 \%$ plutonium routed to the lanthanide product.

Despite the $\mathrm{AHA}+\mathrm{SO}_{3}-\mathrm{Ph}-\mathrm{BTP}$ and glycolic acid strips the results indicated the presence of some residual americium and neptunium in the solvent raffinate (SR1). Analysis of the final solvent samples by alpha spectroscopy also showed that approximately $2.5 \%$ of the neptunium was routed to the solvent raffinate, while $<0.002 \%$ of the plutonium remained in the solvent. Gamma spectroscopy analysis also indicated that up to $0.5 \%$ of the americium was present in the solvent raffinate. However, this is not in agreement with the profile samples which show a lower level of americium was present in the solvent phase of the profile samples prior to the product outlet $(<0.1 \%)$. Therefore, the high residual americium content in the solvent raffinate samples must have been due to some contamination of the product.

\section{Stage profiles}

A more detailed understanding of the flowsheet performance can be obtained by examination of the profile data. Figs. 4-8 illustrate the profile data obtained for plutonium, americium, europium, neptunium and strontium. The acid profile of the extract-scrub contactors was not obtained experimentally but modelling suggested quite steady nitric acid concentrations of $\sim 3$ $\mathrm{mol} / \mathrm{L}$ in the extract section and $\sim 0.5 \mathrm{~mol} / \mathrm{L}$ across the scrub section. Under these conditions, good extraction and recovery of actinides were expected, coupled with efficient scrubbing for fission products (iron and strontium) without excessive accumulations due to recycling in the 
contactor.

\section{$\underline{\text { Plutonium }}$}

The profile for plutonium (Fig. 4) showed rapid extraction at the feed stage (stage 8) and that plutonium was maintained in the organic phase through the scrubbing section, as expected due to the high distribution ratios for plutonium extraction in TODGA[19]. Plutonium was then rapidly stripped from the loaded solvent by $\mathrm{AHA}+\mathrm{SO}_{3}-\mathrm{Ph}-\mathrm{BTP}$ across stages $21-24$. The concentration of plutonium in the solvent and aqueous fell below the limit of detection (for gamma spectroscopy) by stage 24. Profile data indicated that the plutonium was well controlled through the flowsheet.

\section{$\underline{\text { Americium }}$}

The profile for americium (Fig. 5) showed that there was rapid extraction at the feed stage (stage 8) and that americium was maintained in the organic phase through the scrubbing section, as expected due to the high distribution ratios for americium extraction in TODGA[19]. Due to the high recovery of americium, limits of detection were reached in the

aqueous phase by stage 5 , after which it was not possible to detect ${ }^{241} \mathrm{Am}$ by gamma spectroscopy. The conditions in the scrub also maintained sufficiently high distribution values for these species that little stripping was observed in stages 9-16.

The profiles for americium in the strip sections are more complex. The concentration in the organic phase apparently remained almost constant over stages $24-28$ and was significantly higher than the aqueous phase concentration. This indicates that little further backwashing of 
americium occurred over these stages. Despite the lower $\mathrm{SO}_{3}$-Ph-BTP concentration $(0.018$ $\mathrm{mol} / \mathrm{L}$ ) used in this region of the strip contactors this result was unexpected. As the plutonium concentration was also very low in these stages there should have been sufficient excess $\mathrm{SO}_{3}$ Ph-BTP present for backwashing residual americium from the solvent. Batch distribution studies have shown that, in the absence of plutonium, the distribution ratio $\left(\mathrm{D}_{\mathrm{Am}}\right)$ is $\sim 0.06$ with $0.018 \mathrm{~mol} / \mathrm{L} \mathrm{SO}_{3}-\mathrm{Ph}-\mathrm{BTP}+1 \mathrm{~mol} / \mathrm{L}$ AHA solution in $0.5 \mathrm{~mol} / \mathrm{L} \mathrm{HNO}_{3}$. In contrast, $\mathrm{D}_{\mathrm{Am}}$ obtained from the profile samples for stages $24-28$ was between 2 and 8 . It is also apparent that little of the residual americium was stripped by the glycolic acid backwash (stages 29-32) and remained in the solvent raffinate.

\section{Europium}

The profile for europium (Fig. 6) showed that there was rapid extraction at the feed stage (stage 8) and that europium was maintained in the organic phase through the scrubbing section, as expected due to the high distribution ratios for europium extraction in TODGA[19].

The profile for europium showed that some backwashing occurred in the actinide strip contactors but there was little stripping of europium from the solvent across stages 25-28, where the $\mathrm{SO}_{3}$-Ph-BTP concentration was only $0.018 \mathrm{~mol} / \mathrm{L}$. A higher concentration $\mathrm{AHA}+\mathrm{SO}_{3}-\mathrm{Ph}-\mathrm{BTP}$ strip solution was introduced at stage 24 to increase the $\mathrm{SO}_{3}-\mathrm{Ph}-\mathrm{BTP}$ concentration to $0.054 \mathrm{~mol} / \mathrm{L}$. It is evident that some europium was backwashed from the solvent at stages 23 and 24 by the higher $\mathrm{SO}_{3}-\mathrm{Ph}$-BTP concentration in the aqueous strip. The increasing plutonium and americium concentrations around stage 21 helped to suppress the stripping of europium due to increased complexation of $\mathrm{SO}_{3}-\mathrm{Ph}-\mathrm{BTP}$ with americium and 
plutonium. The fresh solvent feed introduced at stage 17 also re-extracted europium that had been co-stripped with the plutonium and americium. However, this was not sufficient to prevent breakthrough of europium into the actinide product and analysis showed $\sim 7 \%$ of the europium was lost to AP2. The stripping and re-extraction of europium resulted in a small recycle in the strip contactors giving a peak in the europium concentration around the loaded solvent feed stage. The rapid decrease in the europium concentration of the solvent phase over stages 29-32 showed that europium was rapidly backwashed from the solvent by the glycolic acid strip. There was also a corresponding increase in the aqueous europium concentration at stage 29.

\section{$\underline{\text { Neptunium }}$}

In contrast to plutonium, americium and europium, the profile for neptunium (Fig. 7) showed that there was a large recycle occurring in the extract-scrub contactors. Neptunium was present in the active feed as a mixture of $\mathrm{Np}(\mathrm{V})$ and $\mathrm{Np}(\mathrm{VI})$. Due to the high nitric acid concentration neptunium was present predominantly as $\mathrm{Np}(\mathrm{VI})[36]$. The profile showed that neptunium was rapidly extracted from the aqueous phase in the stages after the introduction of the active feed. However, the neptunium in the solvent was then backwashed by the $0.5 \mathrm{~mol} / \mathrm{L}$ nitric acid scrub in stages 9-16. Neptunium in the aqueous phase was then re-extracted as the acidity increased around the feed stage. This resulted in a recycle of neptunium across the scrub contactors.

The neptunium profile for the strip sections showed it was rapidly stripped from the loaded solvent by the $\mathrm{AHA}+\mathrm{SO}_{3}-\mathrm{Ph}-\mathrm{BTP}$ solution at stages 21 and 22. After this point there appearred to be a small residual concentration of neptunium in the solvent phase that was not 
backwashed by either the $\mathrm{AHA}+\mathrm{SO}_{3}-\mathrm{Ph}-\mathrm{BTP}$ or glycolic acid strips. This behaviour is unexpected as neptunium was extracted primarily as $\mathrm{Np}(\mathrm{VI})$ into the solvent, which was expected to be rapidly stripped from the solvent by reduction to $\mathrm{Np}(\mathrm{V})$ with $0.5 \mathrm{~mol} / \mathrm{L}$ AHA $\left(\mathrm{D}_{\mathrm{Np}(\mathrm{V})} \sim 0.02\right.$ in $\left.0.5 \mathrm{~mol} / \mathrm{L} \mathrm{HNO}_{3}\right)[21]$.

\section{$\underline{\text { Caesium and strontium }}$}

As expected, caesium was not extracted and, with the exception of aqueous samples from stages 1-8, analytical values were below limits of detection. The profile (not included) simply showed caesium remaining in the aqueous phase and being routed directly to the aqueous raffinate.

However, the profile for strontium (Fig. 8) showed that significant recycle occurred in the extract-scrub contactors. This can be attributed to the change in strontium distribution ratio between the higher acidity region of the extract contactors, where $\mathrm{D}_{\mathrm{Sr}}>1$, and the lower acidity region of the scrub contactors, where $\mathrm{D}_{\mathrm{Sr}}<1$. Consequently, strontium was recycled in the extract-scrub section but eventually broke through into the aqueous raffinate. This test thus confirmed that the $0.5 \mathrm{~mol} / \mathrm{L} \mathrm{HNO}_{3}$ scrub was sufficient to prevent strontium leakage into the strip section of the flowsheet. The potential recycle of iron, which is a corrosion product and will be present in the planned hot test from partial dissolution of the stainless steel fast reactor fuel cladding, was a particular concern with the GANEX flowsheet due to the rapid increase in iron distribution ratio with nitric acid concentration. However, since $\mathrm{D}_{\mathrm{Fe}}<\mathrm{D}_{\mathrm{Sr}}$ on extraction from $3 \mathrm{~mol} / \mathrm{L} \mathrm{HNO}_{3}\left(\mathrm{D}_{\mathrm{Fe}} \sim 0.25 c f . \mathrm{D}_{\mathrm{Sr}} \sim 3\right)$, it is reasonable to assume that recycle of iron will be less severe than observed for strontium and so iron should be routed entirely to the aqueous raffinate. 


\section{PAREX code modelling}

In order to understand better some of the effects seen in the flowsheet test and to optimise the flowsheet design for the subsequent hot test, selected profile data from the flowsheet test were modelled using PAREX (CEA, France); this is a proprietary code designed for solvent extraction process modelling[37].

\section{$\underline{\text { Extract-Scrub Section }}$}

For the extract-scrub section, neptunium and strontium had shown complex behaviour, recycling between aqueous and solvent phases. Therefore, these species were modelled with PAREX. To simplify the modelling, a number of assumptions were made based on available measured distribution ratios; these are listed in Table 4. From these, PAREX calculates concentration profiles. Fig. 9 shows the comparisons between the PAREX model and experimental profiles. For neptunium it is seen that between stages 1 and 8 neptunium extraction is not equivalent to the modelled results (Fig. 9a). This is attributed to the simple treatment used in the model that assumed average distribution ratios rather than specifically accounting for the different oxidation states of neptunium and the kinetics of their interconversions[21]. However, the general trends are reasonably well replicated. In the case of strontium, the PAREX model data are also reasonably close to experimental values (Fig. 9b). The recycle is under-estimated in the extract section and for the scrubbing section, the predicted performance is pessimistic as it under-estimates the decontamination achieved by scrubbing. 


\section{$\underline{\text { Actinide strip }}$}

Plutonium, americium and europium in the strip section of the flowsheet were computer modelled using the PAREX code. Again some assumptions were made to simplify the modelling and fit the experimental data. It is seen that in the flowsheet the separation factors between americium and europium are not as high as in batch distribution experiments, particularly between stages $21-28$. This may be due to differing stage efficiencies (linked to extraction kinetics) but batch distribution data indicated similarly fast kinetics for both species[18]. More likely it is due to some cross-contamination introduced when sampling from the active glove box. Therefore, based on a combination of the distribution ratios observed in the trial and those measured in equilibrium distribution experiments, the distribtion ratios used in the PAREX modelling and the associated separation factors (SF) are given in Table 4. Profile data calculated by PAREX are compared to experimental values in Fig. 10 for europium, plutonium and americium.

From Fig. 10a it is seen that europium behaviour is quite well simulated by the PAREX model, as is plutonium up to the point at which experimental values became too low to measure (Fig. 10b). The aqueous phase americium profile (Fig. 10c) is also well simulated supporting the assumptions made regarding the distribution ratios. The modelled organic profile disagrees with the experimental profile but this is not surprising since the experimental organic profile is thought to be contaminated and the modelling used different distribution ratios and separation factors. 


\section{CONCLUSIONS}

A flowsheet for a novel GANEX process was designed and tested in a spiked flowsheet trial in a 32 stage plutonium-active centrifugal contactor rig. The flowsheet was based on the mixed solvent system of TODGA and DMDOHEMA in a kerosene diluent and used an innovative reagent for selectively stripping actinides in the presence of lanthanides - a sulphonated and therefore hydrophilic BTP complexant. This enabled actinide stripping to be undertaken in the acidic region $>0.1 \mathrm{~mol} / \mathrm{L} \mathrm{HNO}_{3}$ which makes it much easier to engineer and control than processes that have to operate in buffered solutions at $\mathrm{pH}$ 2-4 (i.e. applications of TALSPEAK-type chemistry[38]). Additionally, AHA was used to assist neptunium and plutonium stripping. The flowsheet test met some significant challenges not previously addressed but highly relevant to future industrialisation within the advanced nuclear fuel cycle, including elevated plutonium concentrations (10 g/L) and deployment in short residence time centrifugal contactors. Overall, the trial was successful with high recoveries of the actinide elements. Plutonium, in particular, was well controlled across the flowsheet. Approximately $30 \%$ of neptunium, however, was lost to the aqueous raffinate which was due to non-ideal conditions for neptunium extraction in the extract-scrub. Previous work has shown that high acidities will cause neptunium disproportionation and/or oxidation to more extractable species[21] but the flowsheet was run with lower concentrations of $\mathrm{HNO}_{3}$ in the extract section due to some concern over potential iron and strontium recycle between high acid extract and low acid scrub sections. Consequently there was a large neptunium recycle and break through to the raffinate. We expect that further optimisation of the flowsheet plus the known oxidising effects of spent fuel solutions with regards to neptunium[34] will enable a much higher recovery of neptunium in the planned hot test. Apart from europium, strontium and caesium, we did not measure fission product decontamination factors in this test. Caesium 
was fully routed to the aqueous raffinate but some recycle of strontium was observed in the extract-scrub section; ultimately though strontium was also directed to the raffinate stream. In the stripping section, a small fraction of europium (taken as a model lanthanide ion) was found in the actinide product stream (ca. $7 \%$ ). Some anomalous behaviour of americium was also observed but this has been attributed to probable contamination of the organic profile samples during sampling in the glove box. Modelling of selected data using the PAREX code has shown that even with a relatively simplistic treatment reasonable agreement between modelling and experiment can be obtained, giving confidence in the use of modelling to refine the flowsheet design prior to further testing.

This spiked test has therefore proved the essential concept of this "EURO-GANEX" process although some optimisation is still needed. A PAREX model of the process has been validated against the experimental data and shown to be sufficiently accurate to help optimise the flowsheet design prior to a planned hot test using legacy (ex-Dounreay) irradiated fast reactor fuel. Additional data are still needed on the likely behaviour of other problematic fission products such as zirconium, molybdenum, palladium and technetium, which thus remain significant risks to the successful design of this EURO-GANEX process.

\section{Acknowledgments}

Financial support for this work from European Framework Project "ACSEPT" (FP7-CP2007-211 267), Sellafield Ltd. and the UK Nuclear Decommissioning Authority is gratefully acknowledged. 
Flowsheet test of the GANEX process

Table 1: Composition of high active feed (HAF) simulant

\begin{tabular}{|c|c|c|c|c|}
\hline \multicolumn{3}{|c|}{ Radionuclides } & \multicolumn{2}{|c|}{ Non-radioactive metals (mg/L) } \\
\hline Species & Concentration & Units & Species & Concentration \\
\hline $\mathrm{Pu}$ & 10 & $\mathrm{~g} / \mathrm{L}$ & $\mathrm{Fe}$ & 200 \\
\hline $\mathrm{Np}$ & 200 & $\mathrm{mg} / \mathrm{L}$ & $\mathrm{Cr}$ & 90 \\
\hline Am-241 & 5000 & $\mathrm{MBq} / \mathrm{L}$ & $\mathrm{Ni}$ & 42.4 \\
\hline Sr-85 & 5 & $\mathrm{MBq} / \mathrm{L}$ & $\mathrm{Sr}$ & 149.4 \\
\hline Eu-152 & 5 & $\mathrm{MBq} / \mathrm{L}$ & $\mathrm{Zr}$ & 700 \\
\hline Am-243 & 5 & $\mathrm{MBq} / \mathrm{L}$ & Mo & 646.9 \\
\hline Cs-137 & 5 & $\mathrm{MBq} / \mathrm{L}$ & $\mathrm{Ru}$ & 348 \\
\hline & & & $\mathrm{Pd}$ & 171.4 \\
\hline & Acid & & Cs & 598.8 \\
\hline Species & Concentration & Units & $\mathrm{Ce}$ & 563.4 \\
\hline $\mathrm{HNO}_{3}$ & 5 & $\mathrm{~mol} / \mathrm{L}$ & $\mathrm{Nd}$ & 756.2 \\
\hline CDTA & 0.05 & $\mathrm{~mol} / \mathrm{L}$ & $\mathrm{Eu}$ & 35.5 \\
\hline & & & Dy & 48.3 \\
\hline & & & Ho & 75.2 \\
\hline
\end{tabular}


Flowsheet test of the GANEX process

Table 2: Summary of routings of actinides (\%) and mass balances (\%) across the flowsheet calculated from gamma spectroscopy results. Averages are calculated from the final four samples only (assumed to be steady state values)

\begin{tabular}{|c|c|c|c|c|c|c|}
\hline Element & Time (hr.) & AP1 & AP2 & AP3 & SR1 & $\begin{array}{c}\text { Mass balance }(\%) \\
( \pm 2 \sigma)\end{array}$ \\
\hline \multirow[t]{8}{*}{$\overline{\mathrm{Pu}}$} & 1 & 0.0 & 2.7 & 0.0 & 0.0 & 2.7 \\
\hline & 2 & 0.0 & 79.4 & 0.0 & 0.0 & 79.4 \\
\hline & 3 & 0.0 & 94.6 & 0.0 & 0.0 & 94.6 \\
\hline & 4 & 0.0 & 95.8 & 0.0 & 0.0 & 95.8 \\
\hline & 5 & 0.0 & 100.1 & 0.0 & 0.0 & 100.1 \\
\hline & 6 & 0.0 & 97.0 & 0.0 & 0.0 & 97.0 \\
\hline & 7 & 0.0 & 98.0 & 0.0 & 0.0 & 98.0 \\
\hline & Average & 0.0 & 97.7 & 0.0 & 0.0 & 97.7 (3.6) \\
\hline \multirow[t]{8}{*}{$\mathrm{Am}$} & 1 & 0.0 & 2.1 & 0.0 & 0.0 & 2.1 \\
\hline & 2 & 0.0 & 76.9 & 0.5 & 0.0 & 77.5 \\
\hline & 3 & 0.0 & 87.4 & 0.1 & 0.5 & 88.1 \\
\hline & 4 & 0.0 & 96.5 & 0.1 & 0.5 & 97.2 \\
\hline & 5 & 0.0 & 100.7 & 0.2 & 0.5 & 101.4 \\
\hline & 6 & 0.0 & 97.9 & 0.1 & 0.5 & 98.6 \\
\hline & 7 & 0.0 & 99.4 & 0.1 & 0.5 & 100.1 \\
\hline & Average & 0.0 & 98.6 & 0.1 & 0.5 & $98.6(3.6)$ \\
\hline \multirow[t]{3}{*}{$\mathrm{Np}$} & 1 & 8.9 & 1.3 & 0.0 & 0.0 & 10.2 \\
\hline & 2 & 11.1 & 16.1 & 0.0 & 0.0 & 27.1 \\
\hline & 3 & 16.3 & 0.0 & 0.0 & 6.2 & 22.5 \\
\hline
\end{tabular}


Flowsheet test of the GANEX process

\begin{tabular}{|c|c|cccc|c|}
4 & 20.0 & 32.0 & 0.0 & 0.0 & 51.9 \\
5 & 25.7 & 39.0 & 0.0 & 0.0 & 64.7 \\
6 & 24.9 & 46.3 & 0.0 & 0.0 & 71.2 \\
7 & 25.0 & 49.5 & 0.0 & 0.0 & 74.5 \\
\hline & Average & 23.9 & 41.7 & 0.0 & 0.0 & $65.6(20.0)$ \\
\hline
\end{tabular}


Flowsheet test of the GANEX process

Table 3: Summary of routings of key fission prodcts (\%) and mass balances (\%) across the flowsheet calculated from gamma spectroscopy results. Averages are calculated from the final four samples only (assumed to be steady state values)

\begin{tabular}{|c|c|c|c|c|c|c|}
\hline Element & Time (hr.) & AP1 & AP2 & AP3 & SR1 & $\begin{array}{c}\text { Mass balance }(\%) \\
\qquad( \pm 2 \sigma)\end{array}$ \\
\hline \multirow[t]{8}{*}{$\mathrm{Eu}$} & 1 & 0.0 & 0.3 & 1.5 & 0.0 & 1.9 \\
\hline & 2 & 0.0 & 9.2 & 66.2 & 3.1 & 78.5 \\
\hline & 3 & 0.0 & 0.0 & 84.1 & 0.8 & 84.9 \\
\hline & 4 & 0.0 & 6.3 & 88.3 & 1.0 & 95.5 \\
\hline & 5 & 0.0 & 6.8 & 89.5 & 0.7 & 97.0 \\
\hline & 6 & 0.0 & 6.1 & 87.0 & 0.3 & 93.4 \\
\hline & 7 & 0.0 & 7.5 & 86.8 & 0.0 & 94.3 \\
\hline & Average & 0.00 & 6.7 & 87.9 & 0.5 & $95.1(3.1)$ \\
\hline \multirow[t]{8}{*}{$\mathrm{Sr}$} & 1 & 15.6 & 0.0 & 0.0 & 0.0 & 15.6 \\
\hline & 2 & 60.1 & 0.0 & 0.0 & 0.0 & 60.1 \\
\hline & 3 & 88.7 & 0.0 & 0.0 & 0.0 & 88.7 \\
\hline & 4 & 97.1 & 0.0 & 0.0 & 0.0 & 97.1 \\
\hline & 5 & 94.5 & 0.0 & 0.0 & 0.0 & 94.5 \\
\hline & 6 & 99.3 & 0.0 & 0.0 & 0.0 & 99.3 \\
\hline & 7 & 113.2 & 0.0 & 0.0 & 0.0 & 113.2 \\
\hline & Average & 101.0 & 0.0 & 0.0 & 0.0 & $101.0(16.7)$ \\
\hline \multirow[t]{3}{*}{$\mathrm{Cs}$} & 1 & 102.1 & 0.0 & 0.0 & 0.0 & 102.1 \\
\hline & 2 & 113.9 & 0.0 & 0.0 & 0.0 & 113.9 \\
\hline & 3 & 112.1 & 0.0 & 0.0 & 0.0 & 112.1 \\
\hline
\end{tabular}


Flowsheet test of the GANEX process

\begin{tabular}{|c|c|cccc|c|}
4 & 104.0 & 0.0 & 0.0 & 0.0 & 104.0 \\
5 & 101.8 & 0.0 & 0.0 & 0.0 & 101.8 \\
6 & 98.1 & 0.0 & 0.0 & 0.0 & 98.1 \\
& 7 & 104.9 & 0.0 & 0.0 & 0.0 & 104.9 \\
\hline & Average & 102.2 & 0.0 & 0.0 & 0.0 & $102.2(6.1)$ \\
\hline
\end{tabular}


Table 4: Distribution ratios used in PAREX for the simulation of extraction-scrubbing and actinide stripping sections of the flowsheet

\begin{tabular}{|c|c|c|c|c|c|c|c|c|c|}
\hline \multicolumn{6}{|c|}{ Section: Extract-scrub } & \multicolumn{4}{|c|}{ Section: Actinide strip } \\
\hline & \multicolumn{5}{|c|}{$\mathrm{HNO}_{3}(\mathrm{M})$} & & \multicolumn{3}{|c|}{ Stage numbers } \\
\hline $\mathbf{D}_{\mathbf{X}}$ & 0.5 & 0.6 & 1 & 3 & 3.5 & $\mathbf{D}_{\mathbf{X}} / \mathbf{S F}_{\mathbf{X} / \mathbf{Y}}$ & $17-20$ & 21-24 & $25-28$ \\
\hline $\mathrm{D}_{\mathrm{HNO} 3}$ & 0.2 & 0.2 & 0.2 & 0.2 & 0.2 & $\mathrm{D}_{\mathrm{Eu}}$ & 4.8 & 1.9 & 7.2 \\
\hline $\mathrm{D}_{\mathrm{Sr}}$ & 0.5 & 0.5 & 0.5 & 1.7 & 1.7 & $\mathrm{D}_{\mathrm{Am}}$ & 0.11 & 0.14 & 0.5 \\
\hline $\mathrm{D}_{\mathrm{Np}}$ & 1 & 1.2 & 2 & 2.5 & 4 & $\mathrm{D}_{\mathrm{Pu}}$ & 0.14 & 0.17 & 0.7 \\
\hline & & & & & & $\mathrm{SF}_{\mathrm{Eu} / \mathrm{Am}}$ & 43 & 14 & 14 \\
\hline & & & & & & $\mathrm{SF}_{\mathrm{Eu} / \mathrm{Pu}}$ & 34 & 11 & 10 \\
\hline
\end{tabular}




\section{FIGURE CAPTIONS}

Fig. 1: Schematic of EURO-GANEX process concepts for co-separation of TRU actinides (after an initial uranium separation cycle)

Fig. 2: GANEX process flowsheet tested with list of feeds. EAS indicates position of flow through cell for on-line analysis of AP2 product stream (for HAF composition see Table 1) . Contactor labels refer to: $\mathrm{E}(1-2)=$ Extract banks; $\mathrm{S}(1-2)=$ Scrub; LBW $=$ Lanthanide BackWash; ABW(1-2) = Actinide BackWash; LS1 = Lanthanide Strip

Fig. 3: On-line spectrophotometric monitoring of the $\mathrm{SO}_{3}-\mathrm{Ph}-\mathrm{BTP} \mathrm{Pu}(\mathrm{IV})$ complex in $\mathrm{AP} 2$ using absorption maxima at $792 \mathrm{~nm}$ (baseline corrected for drift at $990 \mathrm{~nm}$ and maximum absorbance normalised to $100 \%$ ) compared to the off-line gamma spectroscopy data

Fig. 4: Plutonium profile across the flowsheet

Fig. 5: Americium profile across the flowsheet

Fig. 6: Europium profile across the flowsheet

Fig. 7: Neptunium profile across the flowsheet (inset: stages 17-28 expanded)

Fig. 8: Strontium profile across the flowsheet

Fig. 9: Profiles across the extract-scrub section (i.e. stages 1-16) for (a) neptunium and (b) strontium. Comparison of experimental data with PAREX model

Fig. 10: Profiles across the actinide stripping section (i.e. stages 17-28) for (a) europium, (b) plutonium and (c) americium. Comparison of experimental data with PAREX model 


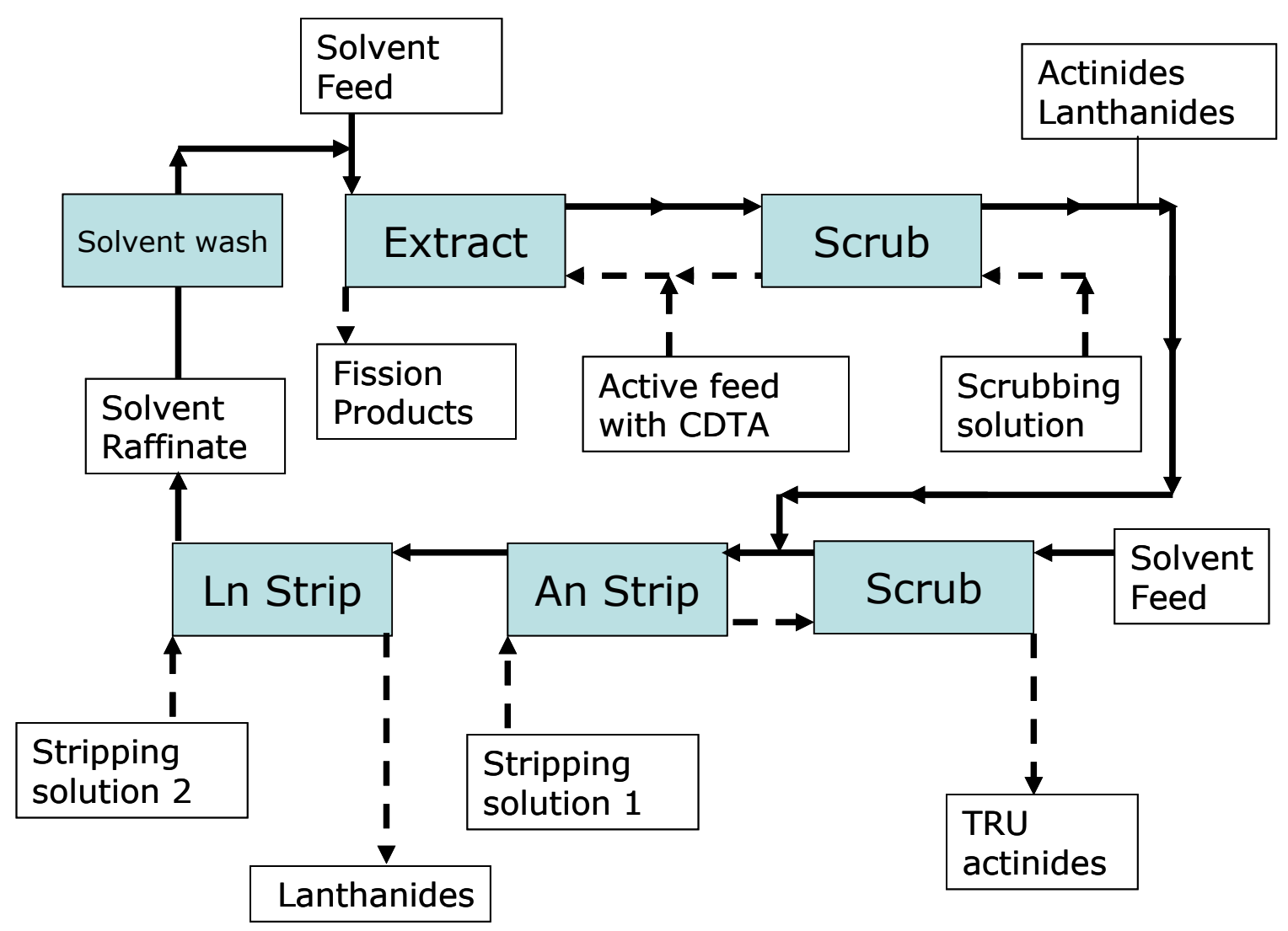

Fig. 1: Schematic of EURO-GANEX process concepts for co-separation of TRU actinides (after an initial uranium separation cycle) 


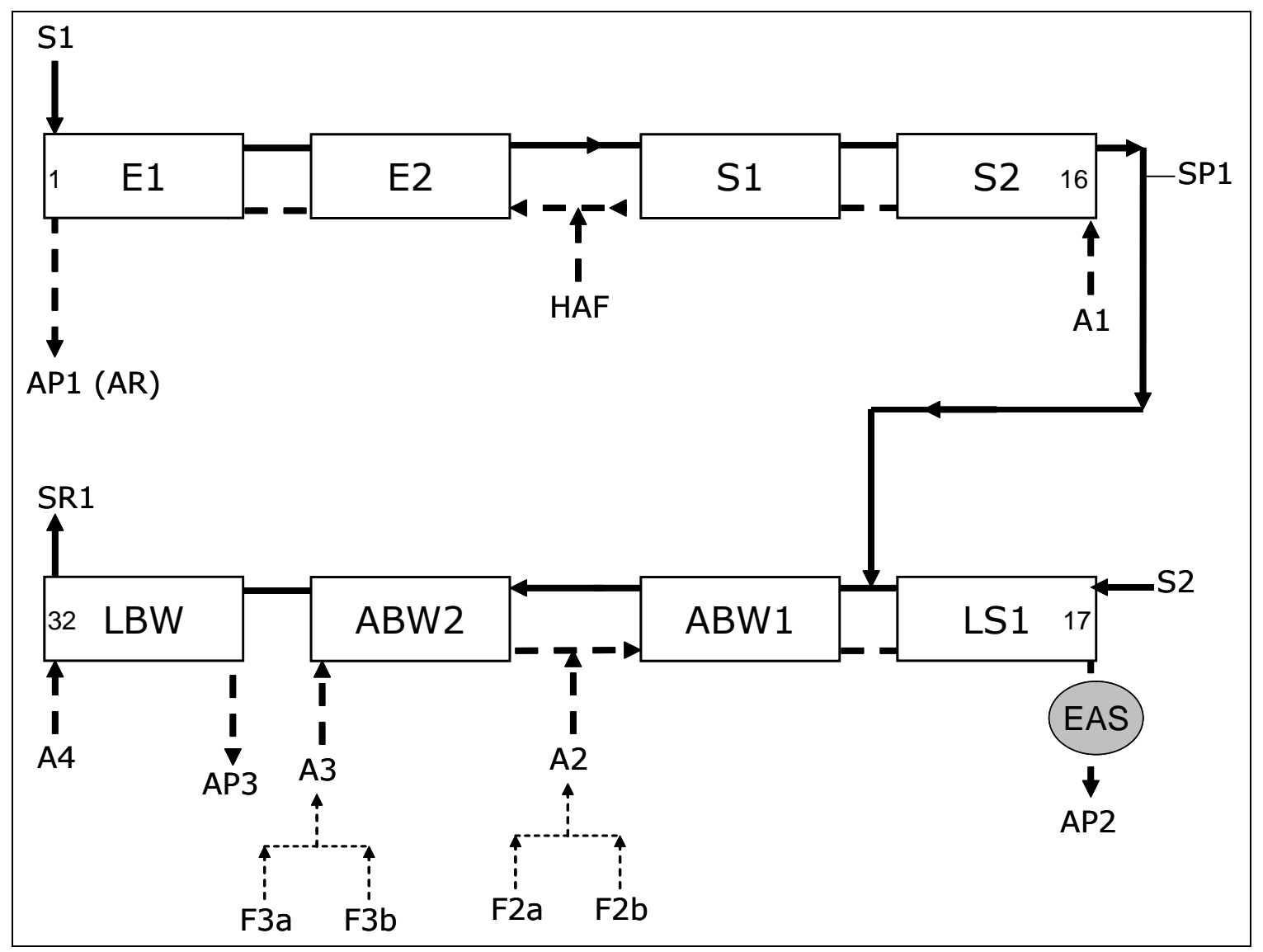

\begin{tabular}{|l|c|c|c|c|c|c|c|c|c|c|c|}
\hline & A1 & HAF & S1 & S2 & F3a & F3b & $\begin{array}{c}\text { A3 } \\
(\text { F3a }+ \text { F3b })\end{array}$ & F2a & F2b & $\begin{array}{c}\text { A2 } \\
(\text { F2a }+ \text { F2b })\end{array}$ & A4 \\
\hline $\mathrm{HNO}_{3}(\mathrm{~mol} / \mathrm{L})$ & 0.50 & 5.0 & & & 1 & & 0.5 & 1 & & 0.5 & \\
\hline AHA (mol/L) & & & & & & 2 & 1 & & 2 & 1 & \\
\hline $\mathrm{BTP}(\mathrm{mol} / \mathrm{L})$ & & & & & & 0.036 & 0.018 & & 0.181 & 0.091 & \\
\hline Glycolic acid (mol/L) & & & & & & & & & & & 0.10 \\
\hline DMDOHEMA(mol/L) & & & 0.50 & 0.50 & & & & & & & \\
\hline TODGA (mol/L) & & & 0.20 & 0.20 & & & & & & & \\
\hline Flowrate (mL/min) & 1.00 & 1.00 & 1.00 & 1.00 & 0.5 & 0.5 & 1.0 & 0.5 & 0.5 & 1.0 & 2.00 \\
\hline
\end{tabular}

Fig. 2: GANEX process flowsheet tested with list of feeds. EAS indicates position of flow through cell for on-line analysis of AP2 product stream (for HAF composition see Table 1) . Contactor labels refer to: $\mathrm{E}(1-2)=$ Extract banks; $\mathrm{S}(1-2)=\mathrm{Scrub}$; LBW = Lanthanide BackWash; ABW(1-2) = Actinide BackWash; LS1 = Lanthanide Strip 
Flowsheet test of the GANEX process

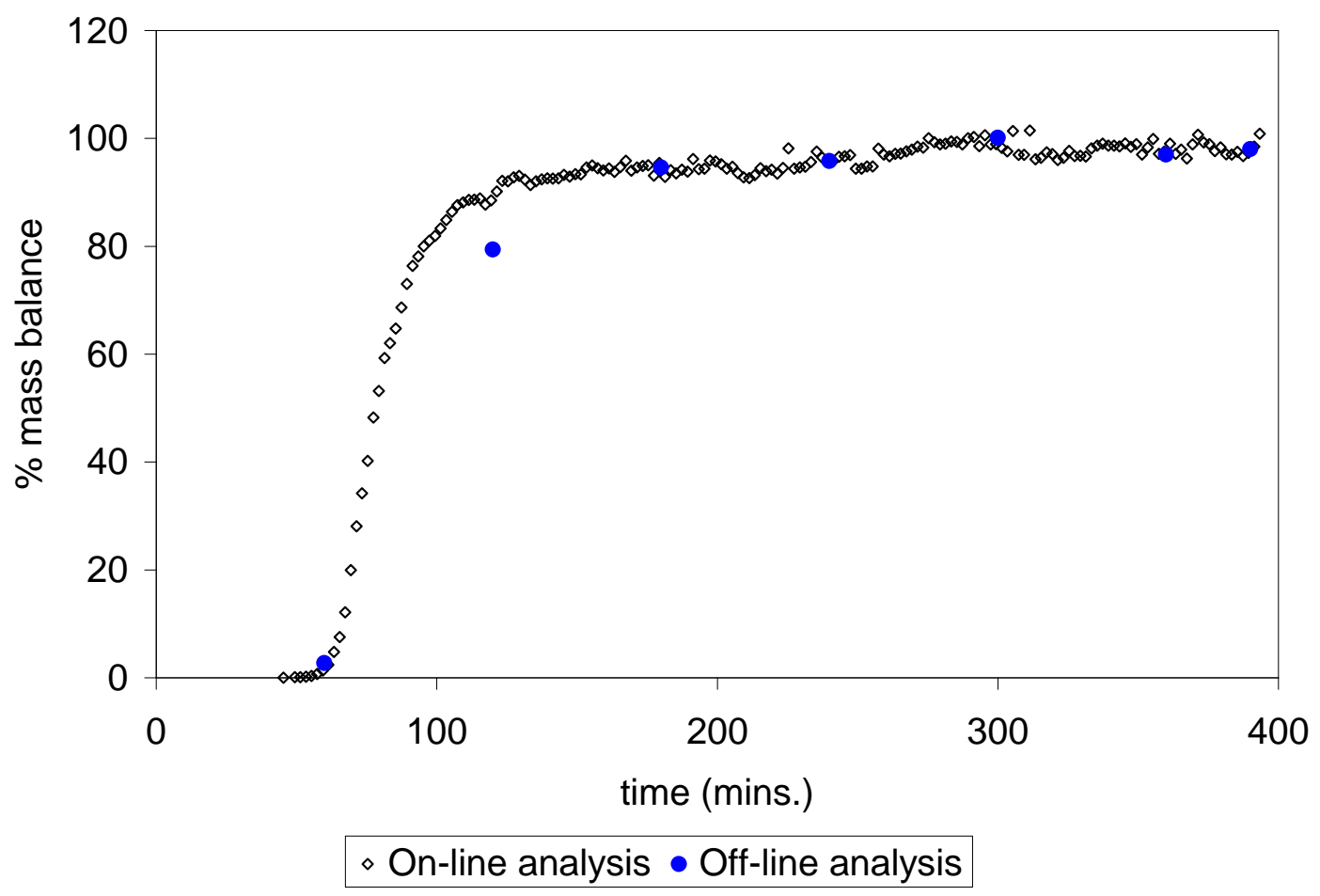

Fig. 3: On-line spectrophotometric monitoring of the $\mathrm{SO}_{3}-\mathrm{Ph}-\mathrm{BTP} \mathrm{Pu}(\mathrm{IV})$ complex in $\mathrm{AP} 2$ using absorption maxima at $792 \mathrm{~nm}$ (baseline corrected for drift at $990 \mathrm{~nm}$ and maximum absorbance normalised to $100 \%$ ) compared to the off-line gamma spectroscopy data 
Flowsheet test of the GANEX process

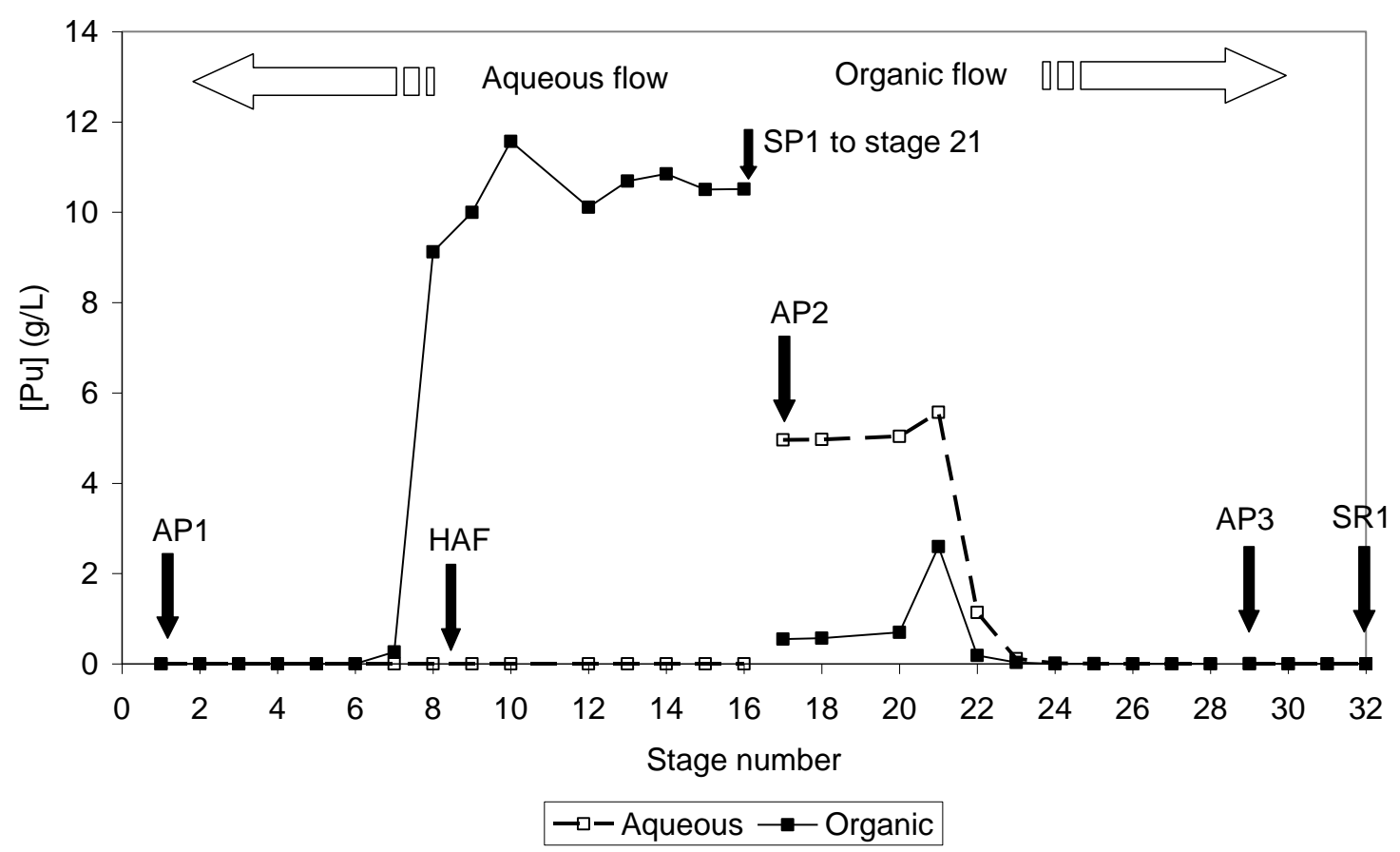

Fig. 4: Plutonium profile across the flowsheet 
Flowsheet test of the GANEX process

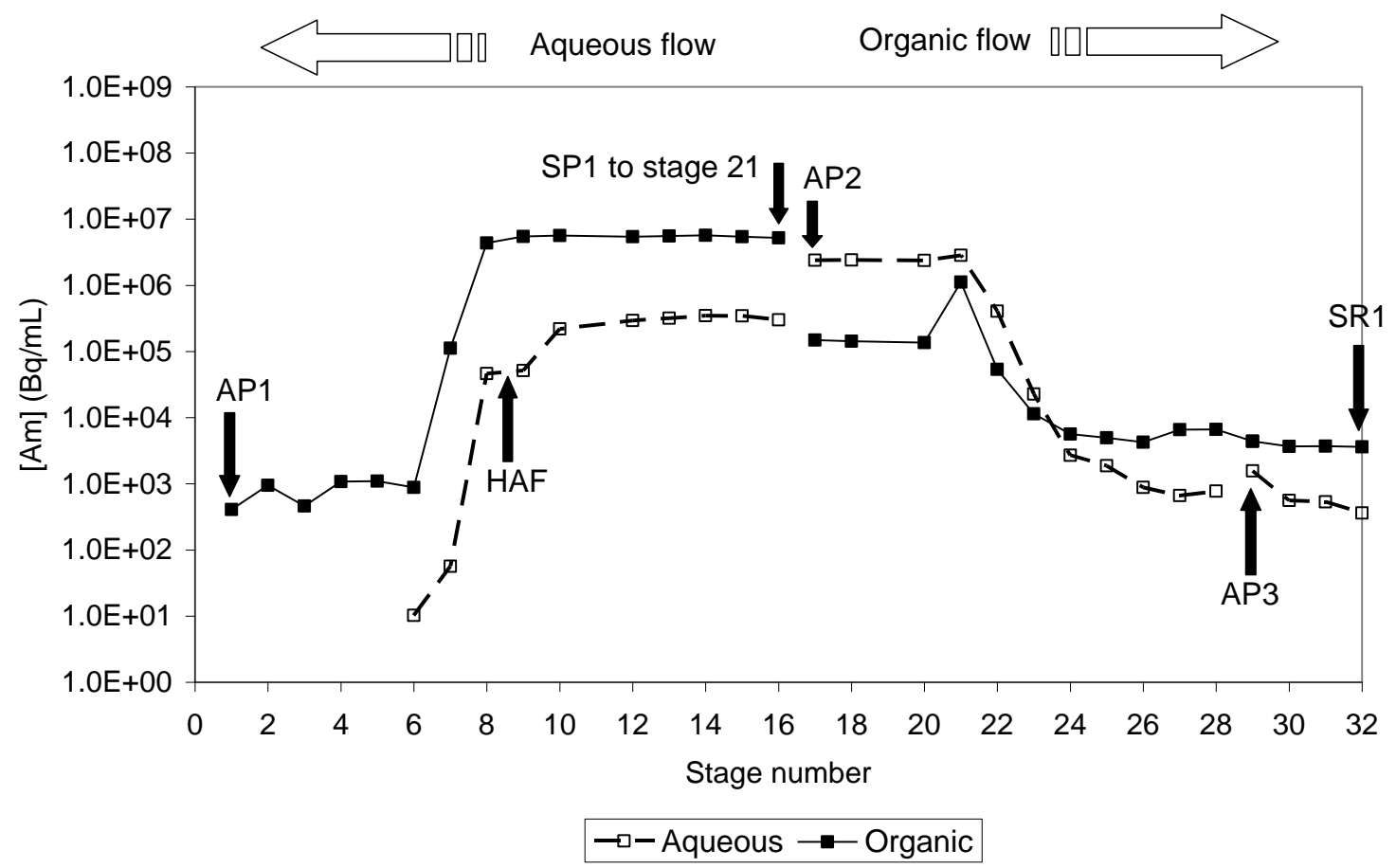

Fig. 5: Americium profile across the flowsheet 
Flowsheet test of the GANEX process

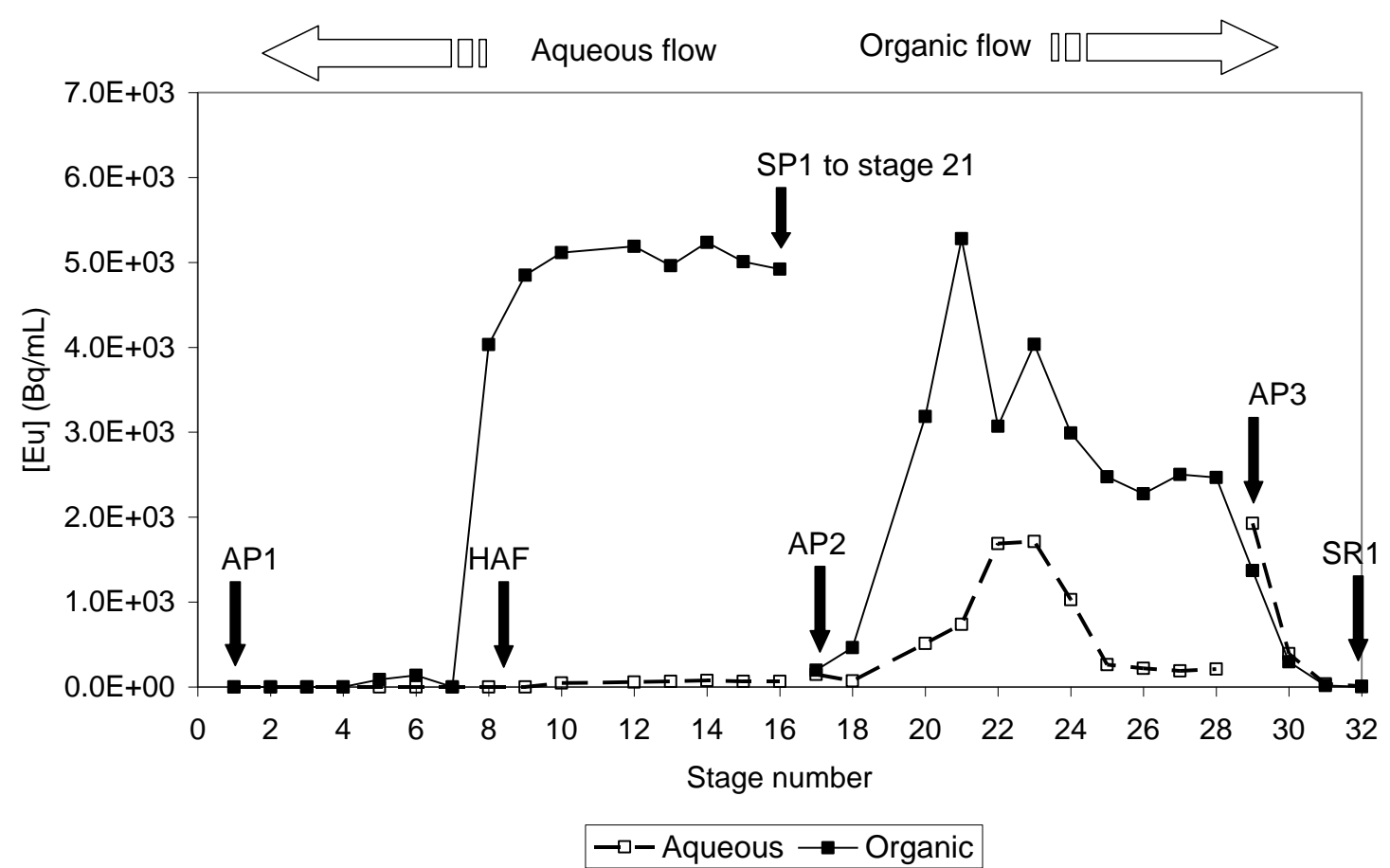

Fig. 6: Europium profile across the flowsheet 
Flowsheet test of the GANEX process

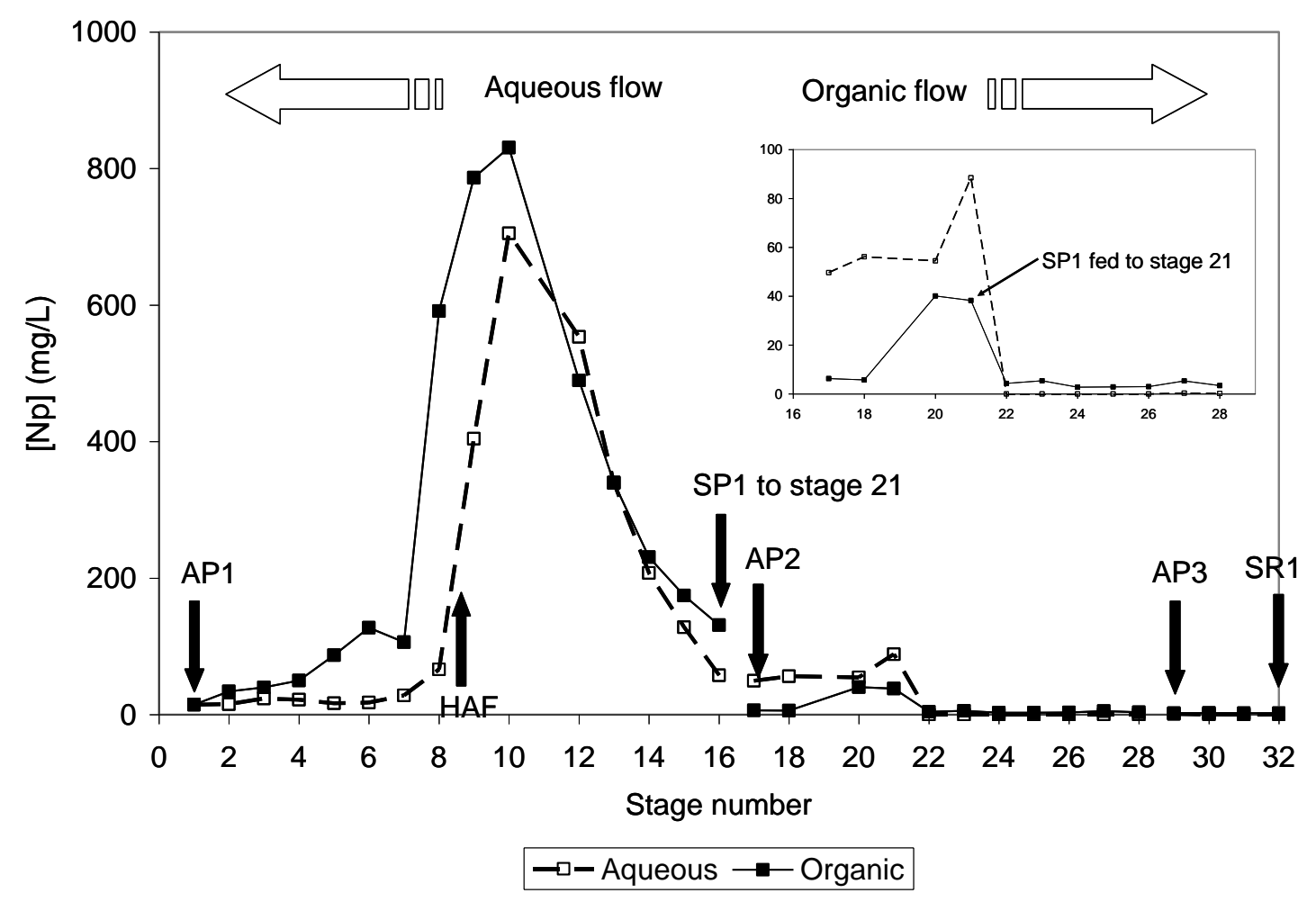

Fig. 7: Neptunium profile across the flowsheet (inset: stages 17-28 expanded) 
Flowsheet test of the GANEX process

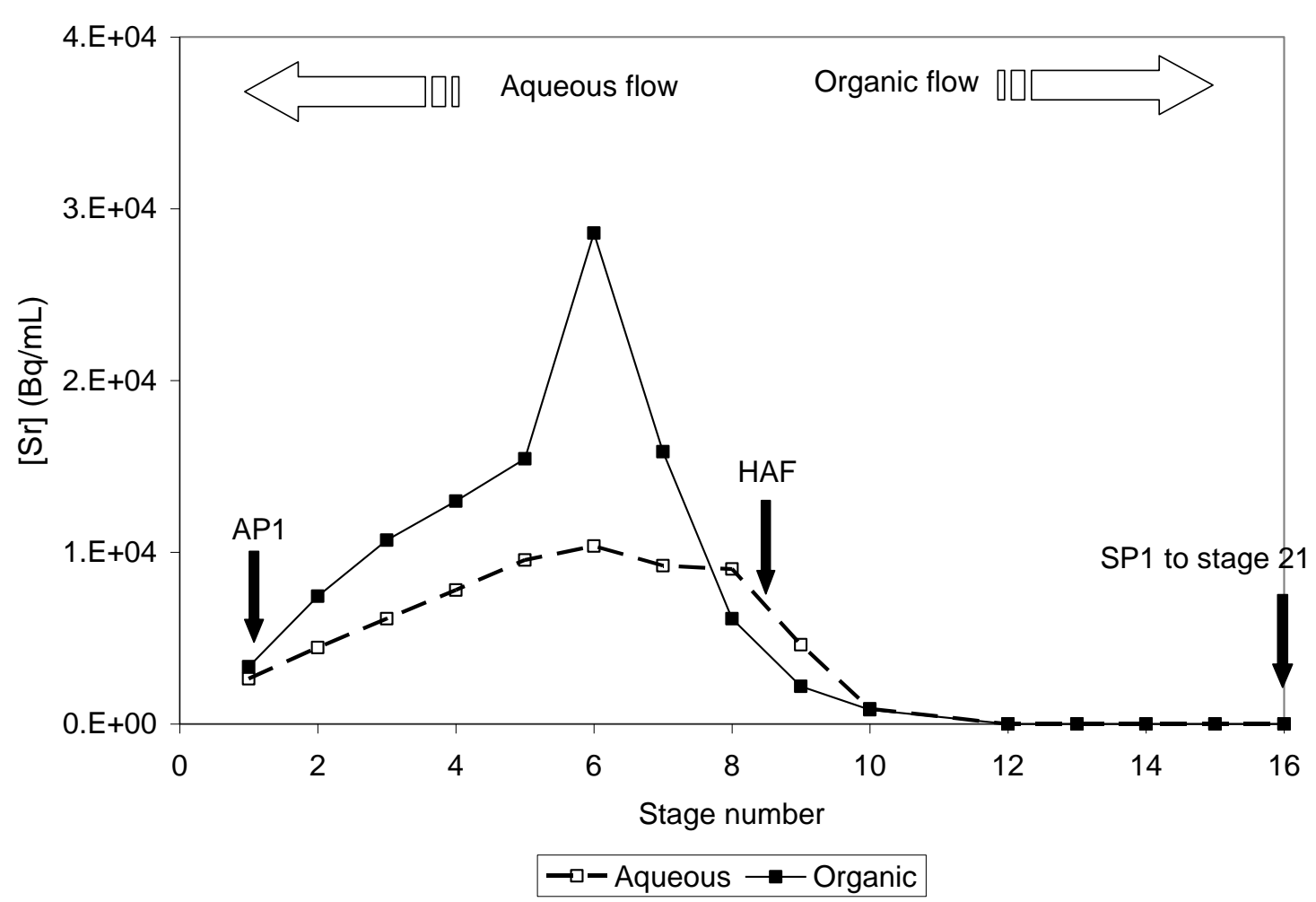

Fig. 8: Strontium profile across the flowsheet 
(a)

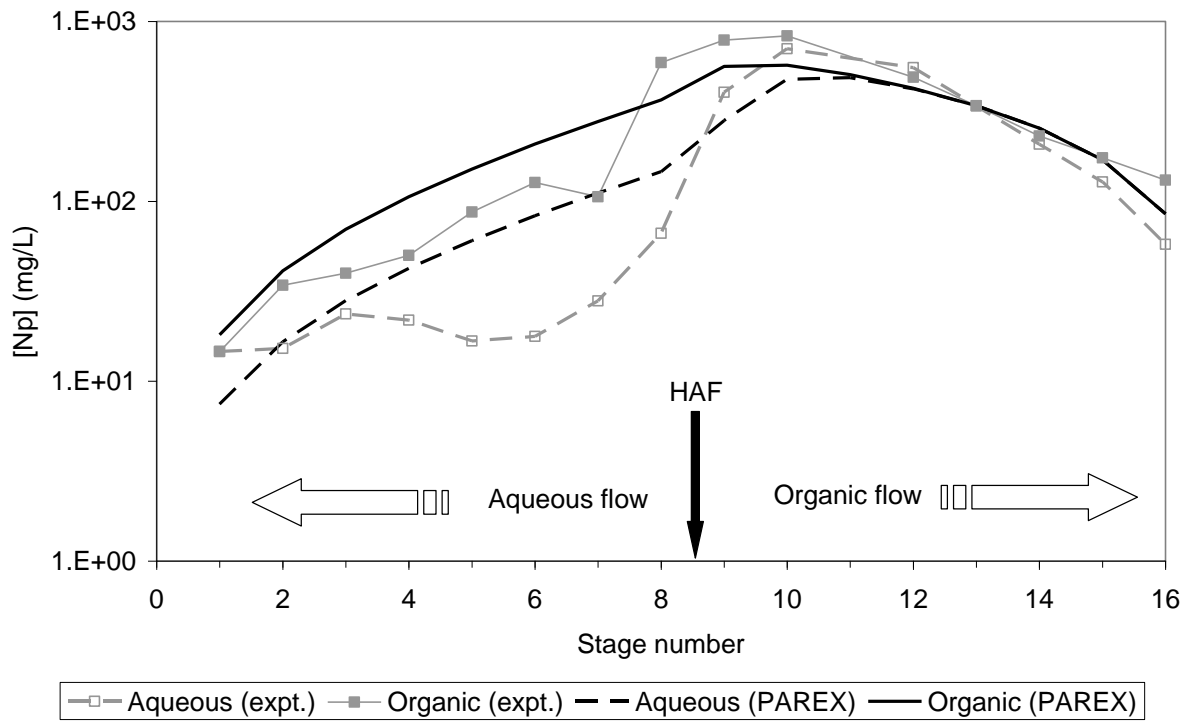

(b)

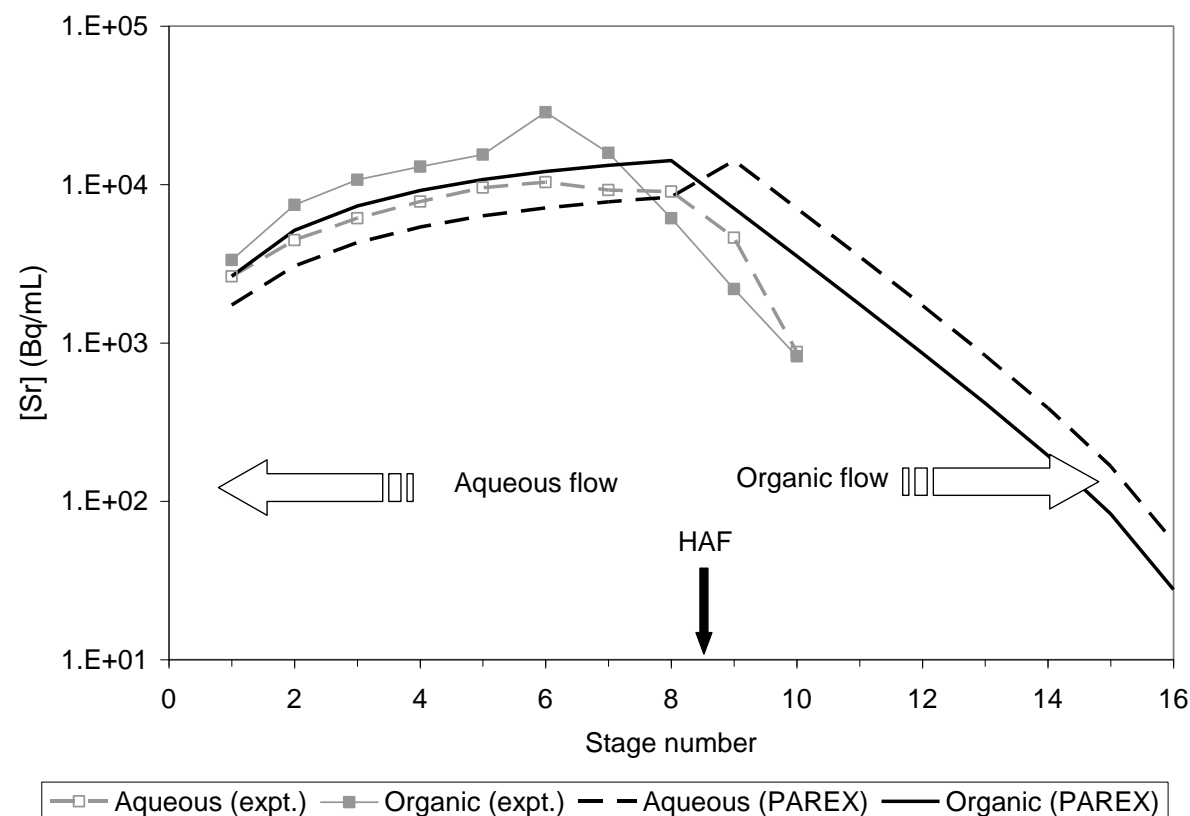

Fig. 9: Profiles across the extract-scrub section (i.e. stages 1-16) for (a) neptunium and (b) strontium. Comparison of experimental data with PAREX model 
(a)

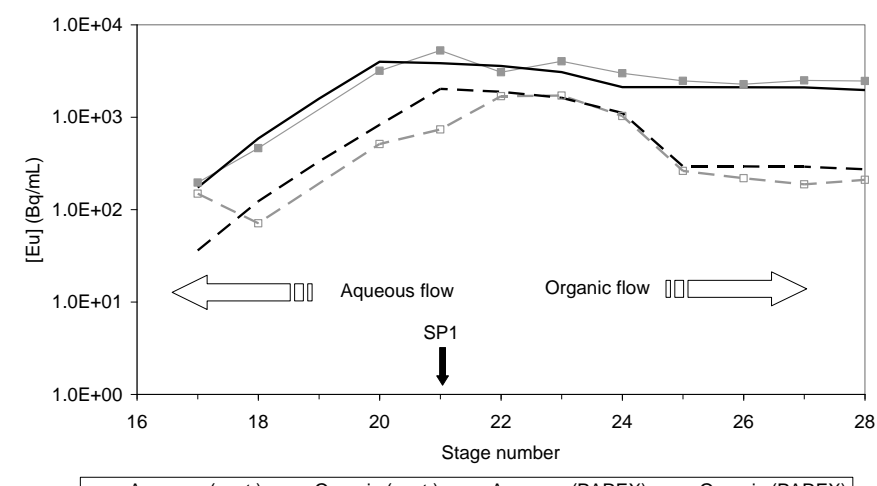

$-\square-$ Aqueous (expt.) $\rightarrow-$ Organic (expt.) -- Aqueous (PAREX) - Organic (PAREX)

(b)

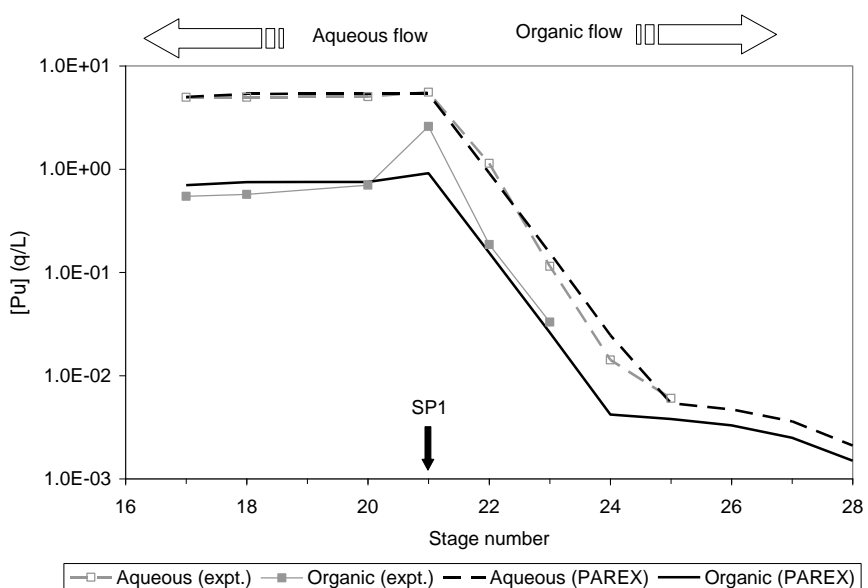

(c)

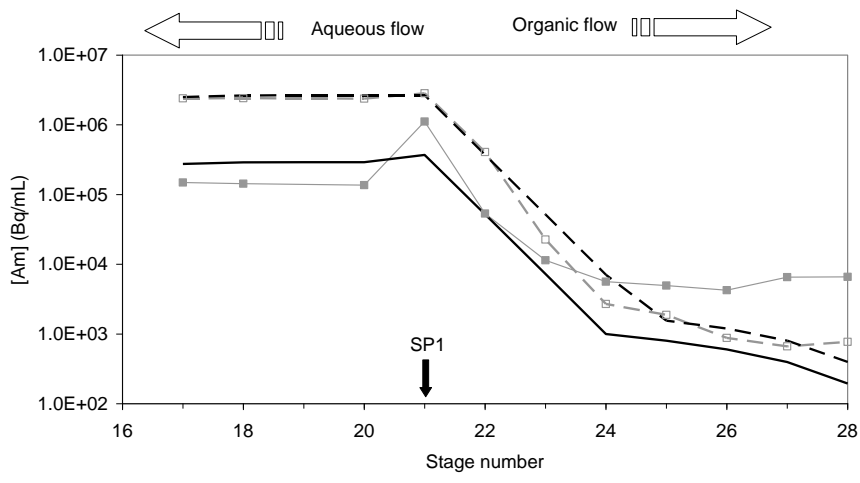

$\rightarrow-$ Aqueous (expt.) $\rightarrow-$ Organic (expt.) -- Aqueous (PAREX) - Organic (PAREX)

Fig. 10: Profiles across the actinide stripping section (i.e. stages 17-28) for (a) europium, (b) plutonium and (c) americium. Comparison of experimental data with PAREX model 


\section{References}

1. $\quad$ www.snetp.eu, "Strategic Research Agenda: Sustainable Nuclear Energy Technology Platform". 2009.

2. Warin, D.; Boullis, B. Future nuclear fuel cycles: prospect and challenges. In Actinide and fission product partitioning and transmutation, 10th Information Exchange meeting, Ed.; Nuclear Energy Agency, OECD: Paris. 2010; pp. 221-226.

3. Bourg, S.; Hill, C.; Caravaca, C.; Rhodes, C.; Ekberg, C.; Taylor, R.; Geist, A.; Modolo, G.; Cassayre, L.; Malmbeck, R.; Harrison, M.; de Angelis, G.; Espartero, A.; Bouvet, S.; Ouvrier, N. ACSEPT--Partitioning technologies and actinide science: Towards pilot facilities in Europe. Nuclear Engineering and Design, 2011, 241; 3427 3435.

4. Madic, C.; Boullis, B.; Baron, P.; Testard, F.; Hudson, M. J.; Liljenzin, J. O.; Christiansen, B.; Ferrando, M.; Facchini, A.; Geist, A.; Modolo, G.; Espartero, A. G.; De Mendoza, J. Futuristic back-end of the nuclear fuel cycle with the partitioning of minor actinides. Journal of Alloys and Compounds, 2007, 444-445; 23-27.

5. Birkett, J. E.; Carrott, M. J.; Fox, O. D.; Jones, C. J.; Maher, C. J.; Roube, C. V.; Taylor, R. J.; Woodhead, D. A. Recent Developments in the Purex Process for Nuclear Fuel Reprocessing: Complexant Based Stripping for Uranium - Plutonium Separation. Chimia, 2005, 59; 898-904.

6. Warin, D. Future nuclear fuel cycles: Prospect and challenges for actinide recycling. IOP Conference Series: Materials Science and Engineering, 2010, 9(1); 012063.

7. Miguirditchian, M.; Chareyre, L.; Hérès, X.; Hill, C.; Baron, P.; Masson, M. GANEX: Adaptation of the DIAMEX-SANEX Process for the Group Actinide Separation. In Proc. GLOBAL 2007, Advanced Nuclear Fuel Cycles and Systems. 2007. Boise, Idaho: American Nuclear Society: La Grange Park, Illinois, 550-552.

8. Miguirditchian, M.; Sorel, C.; Camès, B.; Bisel, I.; Baron, P. Extraction of uranium (VI by N,N-di(2-ethylhexyl)isobutyramide (DEHIBA): from the batch experimental data to the countercurrent process. In Solvent extraction: fundamentals to industrial applications. Proceedings ISEC 2008 International Solvent Extraction conference; Moyer, B. A., Ed.; Can. Inst. Min. Metall. Pet.: Montreal, Canada. 2008; pp. 721-726.

9. Miguirditchian, M.; Roussel, H.; Chareyre, L.; Baron, P. HA demonstration in the Atalante facility of the GANEX 2nd cycle for the grouped TRU extraction. In GLOBAL 2009. 2009. Paris, France: American Nuclear Society: La Grange Park, Illinois, 9378.

10. Herbst, R. S.; Baron, P. Standard and advanced separation: PUREX processes for nuclear fuel reprocessing. In Advanced separation techniques for nuclear fuel reprocessing and radioactive waste treatment; Nash, K. L., Lumetta, G. J., Ed.; Woodhouse Publishing Ltd.: Oxford. 2011; pp. 141-175.

11. Ansari, S. A.; Pathak, P. N.; Manchanda, V. K.; Husain, M.; Prasad, A. K.; Parmar, V. S. N,N,N $\mathrm{N}^{\prime}, \mathrm{N}^{\prime}$-Tetraoctyl Diglycolamide (TODGA): A Promising Extractant for Actinide-Partitioning from High-Level Waste (HLW). Solvent Extraction and Ion Exchange, 2005, 23(4); 463-479.

12. Mowafy, E. A.; Aly, H. F. Synthesis of some $\mathrm{N}, \mathrm{N}, \mathrm{N}^{\prime}, \mathrm{N}^{\prime}$-Tetraalkyl-3-OxaPentane-1,5-Diamide and their Applications in Solvent Extraction. Solvent Extraction and Ion Exchange, 2007, 25(2); 205-224.

13. Sasaki, Y.; Sugo, Y.; Suzuki, S.; Tachimori, S. The Novel Extractants, Diglycolamides, For The Extraction Of Lanthanides And Actinides In $\mathrm{HNO}_{3}-\mathrm{n}$ Dodecane System. Solvent Extraction and Ion Exchange, 2001, 19(1); 91-103. 
14. Sasaki, Y.; Tachimori, S. Extraction of actinides(III), (IV), (V), (VI), and lanthanides(III) by structurally tailored diamides. Solvent Extraction and Ion Exchange, 2002, 20(1); 21-34.

15. Zhu, Z.-X.; Sasaki, Y.; Suzuki, H.; Suzuki, S.; Kimura, T. Cumulative study on solvent extraction of elements by $\mathrm{N}, \mathrm{N}, \mathrm{N}^{\prime}, \mathrm{N}^{\prime}$-tetraoctyl-3-oxapentanediamide (TODGA) from nitric acid into n-dodecane. Analytica Chimica Acta, 2004, 527(2); 163-168.

16. Modolo, G.; Asp, H.; Schreinemachers, C.; Vijgen, H. Development of a TODGA based Process for Partitioning of Actinides from a PUREX Raffinate Part I: Batch Extraction Optimization Studies and Stability Tests. Solvent Extraction and Ion Exchange, 2007, 25(6); 703-721.

17. Brown, J.; Carrott, M. J.; Fox, O. D.; Maher, C. J.; Mason, C.; McLachlan, F.; Sarsfield, M. J.; Taylor, R. J.; Woodhead, D. A. Screening of TODGA/TBP/OK solvent mixtures for the grouped extraction of actinides. IOP Conference Series: Materials Science and Engineering, 2010, 9(1); 012075.

18. Brown, J.; McLachlan, F.; Sarsfield, M. J.; Taylor, R. J.; Modolo, G.; Wilden, A. Plutonium loading of prospective grouped actinide extraction (GANEX) solvent systems based on diglycolamide extractants. Solvent Extraction and Ion Exchange, 2012, 30; 127-141.

19. Bell, K.; Carpentier, C.; Carrott, M.; Geist, A.; Gregson, C.; Hérès, X.; Magnusson, D.; Malmbeck, R.; McLachlan, F.; Modolo, G.; Müllich, U.; Sypula, M.; Taylor, R.; Wilden, A. Progress towards the development of a new GANEX process. Procedia Chemistry, 2012, 7; 392-397.

20. Sypula, M.; Wilden, A.; Schreinemachers, C.; Malmbeck, R.; Geist, A.; Taylor, R.; Modolo, G. Use of polyaminocarboxylic acids as hydrophilic masking agents for fission products in actinide partitioning processes. Solvent Extraction and Ion Exchange, 2013, 3; 748-764.

21. Carrot, M. J.; Gregson, C. R.; Taylor, R. J. Neptunium Extraction and Stability in the GANEX Solvent: 0.2 M TODGA/0.5 M DMDOHEMA/Kerosene. Solvent Extraction and Ion Exchange, 2012, 31(5); 463-482.

22. Aneheim, E.; Ekberg, C.; Fermvik, A.; Foreman, M. R. S. J.; Retegan, T.; Skarnemark, G. A TBP/BTBP-based GANEX Separation Process. Part 1: Feasibility. Solvent Extraction and Ion Exchange, 2010, 28(4); 437 - 458.

23. Geist, A.; Müllich, U.; Magnusson, D.; Kaden, P.; Modolo, G.; Wilden, A.; Zevaco, T. Actinide(III)/Lanthanide(III) Separation Via Selective Aqueous Complexation of Actinides(III) using a Hydrophilic 2,6-Bis(1,2,4-Triazin-3-Yl)-Pyridine in Nitric Acid. Solvent Extraction and Ion Exchange, 2012, 30(5); 433-444.

24. Hill, C. Development of highly selective compounds for solvent extraction processes: partitioning and transmutations of long-lived radionuclides from spent nuclear fuels. In Advanced separation techniques for nuclear fuel reprocessing and radioactive waste treatment; Nash, K. L., Lumetta, G. J., Ed.; Woodhouse Publishing Ltd.: Oxford. 2011; pp. 311-362.

25. Panak, P. J.; Geist, A. Complexation and Extraction of Trivalent Actinides and Lanthanides by Triazinylpyridine N-Donor Ligands. Chemical Reviews, 2013, 113(2); 1199-1236.

26. Carrott, M.; Geist, A.; Malmbeck, R.; Müllich, U.; Taylor, R., Unpublished data. 2013.

27. Matteson, B. S.; Precek, M.; Paulenova, A. A study of the kinetics of the reduction of neptunium(VI) by acetohydroxamic acid in perchloric acid IOP Conference Series: Materials Science and Engineering, 2010, 9; 012073 
28. Taylor, R. J.; Sinkov, S. I.; Choppin, G. R.; May, I. Solvent Extraction Behavior of Neptunium (IV) Ions between Nitric Acid and Diluted 30\% Tributyl Phosphate in the Presence of Simple Hydroxamic Acids. Solvent Extraction and Ion Exchange, 2007, 26(1); 41-61.

29. Carrott, M. J.; Fox, O. D.; Maher, C. J.; Mason, C.; Taylor, R. J.; Sinkov, S. I.; Choppin, G. R. Solvent Extraction Behavior of Plutonium (IV) Ions in the Presence of Simple Hydroxamic Acids. Solvent Extraction and Ion Exchange, 2007, 25(6); 723 745.

30. Modolo, G.; Asp, H.; Vijgen, H.; Malmbeck, R.; Magnusson, D.; Sorel, C. Demonstration of a TODGA-Based Continuous Counter-Current Extraction Process for the Partitioning of Actinides from a Simulated PUREX Raffinate, Part II: Centrifugal Contactor Runs. Solvent Extraction and Ion Exchange, 2008, 26(1); 62-76.

31. Magnusson, D.; Geist, A.; Malmbeck, R.; Modolo, G.; Wilden, A. Flow-Sheet Design for an Innovative SANEX Process Using TODGA and SO3-Ph-BTP. Procedia Chemistry, 2012, 7(0); 245-250.

32. Geist, A.; Modolo, G.; Wilden, A.; Kaufholz, P. Minor actinide separation: simplification of the DIAMEX-SANEX strategy by means of novel SANEX processes. In Proc. Internat. Conf. GLOBAL 2013. 2013. Salt Lake City, U.S.A.: American Nuclear Society

33. Modolo, G. W., A; Kaufholz, P.; Bosbach, D; Geist, A. Development and demonstration of innovative partitioning processes (i-SANEX and one-cycle SANEX) for actinide partitioning. Progress in nuclear energy, 2013, In print.

34. Taylor, R. J.; Gregson, C. R.; Carrott, M. J.; Mason, C.; Sarsfield, M. J. Progress towards the Full Recovery of Neptunium in an Advanced PUREX Process. Solvent Extraction and Ion Exchange, 2013, 31(4); 442-462.

35. Wilden, A.; Schreinemachers, C.; Sypula, M.; Modolo, G. Direct Selective Extraction of Actinides (III) from PUREX Raffinate using a Mixture of $\mathrm{CyMe}_{4} \mathrm{BTBP}$ and TODGA as 1-cycle SANEX Solvent. Solvent Extraction and Ion Exchange, 2011, 29(2); 190-212.

36. Drake, V. A. Extraction chemistry of neptunium. In Science and technology of tributyl phosphate; Schulz, W. W., Burger, L. L., Navratil, J. D., Bender, K. P., Ed.; CRC Press Inc.: Boca Raton, Florida. 1990; pp. 123-146.

37. Lecomte, M., Ed. Treatment and recycling of spent nuclear fuel: actinide partitioning - application to waste management Nuclear Energy Division Monograph, Ed. Parisot, J.-F. 2008, CEA Saclay: Paris.

38. Nilsson, M.; Nash, K. L. Review Article: A Review of the Development and Operational Characteristics of the TALSPEAK Process. Solvent Extraction and Ion Exchange, 2007, 25(6); 665-701. 